\title{
NOISE VS. NEWS IN EQUITY RETURNS
}

\author{
ROBERT S. CHIRINKO \\ HISHAM FOAD
}

\section{CESIFO WORKING PAPER NO. 1812 \\ CATEGORY 6: MONETARY POLICY AND INTERnATIONAL FinANCE \\ SEPTEMBER 2006}

\footnotetext{
An electronic version of the paper may be downloaded

- from the SSRN website: www.SSRN.com

- from the RePEc website: www.RePEc.org

- from the CESifo website: www.CESifo-group.de
} 


\title{
NOISE VS. NEWS IN EQUITY RETURNS
}

\begin{abstract}
What role does noise play in equity markets? Answering this question usually leads immediately to specifying a model of fundamentals and hence the pervasive joint hypothesis quagmire. We avoid this dilemma by measuring noise volatility directly by focusing on the behavior of country closed-end funds (CCEF's) during foreign (i.e., non-U.S.) holidays - for example, the last days of Ramadan in Islamic countries. These holiday periods are times when the flow of fundamental information relevant to foreign equity markets is substantially reduced and hence trading of CCEF's in U.S. markets can be responding only weakly, if at all, to fundamental information. We find that, controlling for the effects of industry and global shocks and of the overall U.S. market, there remains a substantial amount of noise in the equity returns of U.S. CCEF's. In the absence of noise, the noise ratio statistic would be near zero. However, our results indicate statistically significant departures from zero, with values averaged over all U.S. CCEF's ranging from 76-84\% depending on assumptions about the leakage of information during holiday periods and kurtosis. Noise is negatively related to institutional ownership of U.S. CCEF's and is much less important for U.K. CCEF's. The lower levels of noise for matched U.K. and U.S. CCEF's suggest that the U.K. securities transaction tax is effective in reducing stock market noise.
\end{abstract}

JEL Code: G1, G14, G18.

Keywords: equity market noise, inefficient markets, institutional ownership, securities transaction tax, closed-end funds.

\author{
Robert S. Chirinko \\ Department of Economics \\ Emory University \\ Atlanta, Georgia 30322-2240 \\ USA \\ robert.chirinko@emory.edu
}

\author{
Hisham Foad \\ Department of Economics \\ San Diego State University \\ San Diego, California 92182 \\ USA \\ hfoad@mail.sdsu.edu
}

September 2006

The authors would like to thank Laurent Calvet, Robert Engle, Nicholas Kiefer, Stephen LeRoy, Marc-Andeas Mündler, Jeff Pontiff, Giovanni Urga, and participants at the 2005 Econometric Society World Congress, a Bank of England seminar, and the Kellogg/Northwestern Accounting Research Lunch Group (especially Linda Vincent) for helpful discussions and comments and Marilyn Parr, Lee Pasackow, and Krishna Shivaramakrishnan for vital assistance with data collection. We are especially grateful to Owen Beelders and Çaglar Özden for discussions at the early stages of this project. All errors and omissions remain the sole responsibility of the authors, and the conclusions do not necessarily reflect the views of the organizations with which they are associated. 
Noise vs. News In Equity Returns

\section{Table Of Contents}

I. Introduction

II. Baseline Evidence

III. Refinements

A. Kurtosis

B. A Double Mixture Model Of Returns

IV. Institutional Ownership

V. The United Kingdom And The Securities Transaction Tax

VI. Discussion

VII. Conclusions

References

Appendix: The Double Mixture Model Of Returns:

Derivation Of The Likelihood Function And

Likelihood Ratio Test

Tables 


\section{Noise vs. News In Equity Returns}

The quick and accurate reaction of security prices to information, as well as the non-reaction to noninformation, are the two broad predictions of the efficient markets hypothesis.

Shleifer (2000, p. 5)

Perhaps no single empirical issue is of more fundamental importance to both the fields of financial economics and macroeconomics than the question of whether or not stock prices are a well-informed and rational assessment of the value of future earnings available to stockholders.

Fischer and Merton (1984, p. 94)

... it makes a great deal of difference to an investment market whether or not they [skilled long-term investors] predominate in their influence over the game-players.

Keynes (1936, p. 156)

\section{Introduction}

What role does noise play in equity markets? Textbooks provide elegant treatments that describe how rational investors use information to value equities and extract the subsequent implications for equity prices. In the 1980's, research began to suggest that there is substantial distance between this textbook view and the actual performance of equity markets. For example, Shiller (1981) LeRoy and Porter (1981), and West (1988) show that equity prices are too volatile to be consistent with a net present value model based on fundamentals. Cutler, Poterba, and Summers (1989) and Roll $(1984,1988)$ document the surprising inability of fundamental economic variables and important macroeconomic news known 
ex-post to explain equity returns. Many other studies - surveyed by LeRoy (1989), Shiller (1990), and Campbell, Lo, and MacKinlay (1997) and collected in Thaler $(1993,2005)$ - have highlighted several important problems with the view that equity prices conform to the two broad predictions of the efficient markets hypothesis mentioned by Shleifer in the above quotation. ${ }^{1}$

A quantitatively important role for noise -- market outcomes based on noninformation (Black, 1986) or "heuristics rather than Bayesian rationality" (Shleifer, 2000 , p. 12) -- raises serious doubts as to whether equity markets are able to discharge their central function of allocating resources. ${ }^{2}$ Noise disrupts equity markets in several ways. Discount rates are raised by noise, thus lowering the level of the equilibrium capital stock and pressuring managers to adopt a shortterm focus. ${ }^{3}$ If noise is concentrated in certain industries (e.g., where intangible capital and information technologies are important), resources directed through equity markets may be seriously misallocated. Noise raises the cost of risk arbitrage and thus curbs the capacity of arbitrageurs to align market values with fundamental values. If Keynes' "game players" loom large, equity markets may be unable to allocate capital efficiently. ${ }^{4}$ Moreover, noise creates deadweight losses,

${ }^{1}$ See Malkiel (2003) and Shiller (2003) for an informative recent exchange about the status of the efficient markets hypothesis.

2 This list of problems stemming from noise is drawn from Shleifer and Summers (1990), Shiller (1990), and Shleifer (2000).

${ }^{3}$ De Long, Shleifer, Summers and Waldman (1990) present a model of noise trading risk, and Lee, Shleifer, and Thaler (1991) provide theoretical arguments and empirical evidence that noise qua investor sentiment is a systematic risk factor raising the required equity return. This result is controversial; see the spirited exchange between Chen, Kan and Miller (1993) and Chopra, Lee, Shleifer, and Thaler (1993). Even if noise is idiosyncratic, it can raise the required equity return through unbalanced portfolios (Levy, 1978; Malkiel and Xu, 2002) or information risk (Easley, Hvidkjaer, and O'Hara, 2002). Goyal and Santa-Clara (2003) document that idiosyncratic risk predicts aggregate returns. Their key result is confirmed by Ball, Cakici, Yan, and Zhang (2005) and Brown and Ferreira (2005), who argue that it is limited to small firms.

${ }^{4}$ Inefficiencies created by noise are the driving force in the "fundamental indexation" approach 
as real resources need to be expended to disentangle noise from fundamentals. Noise-induced movements in equity prices may lead to the onset of bubbles, and bursting bubbles have substantial impacts on real spending. ${ }^{5}$ This channel is amplified by the increasing proportion of assets held in equities and may well disrupt efforts by policymakers to stabilize the macroeconomy.

How much of the volatility in equity returns can be attributed to noise relative to news? Addressing this question usually leads immediately to specifying a model of fundamentals and the pervasive joint hypothesis quagmire (Fama, 1970, 1991), which implies that, in any asset pricing model, the volatility attributable to noise can equally well be interpreted as the volatility attributable to specification error. This criticism necessarily confronts prior studies decomposing returns into fundamental and noise components. These studies calculate noise by estimating the volatility attributable to fundamentals and then subtracting this estimate from overall volatility. Since noise volatility is a residual in this procedure, specification errors in the fundamental model are impounded in the subsequent measure of noise. Noise in the eyes of one researcher is specification error in the eyes of another.

We avoid this quagmire by measuring noise volatility directly. We are able to employ a direct estimation strategy by focusing on the behavior of country closed-end funds (CCEF's) during holidays in foreign markets, where the latter is defined for purposes of this paper as the local equity market for countries other than the United States (or the United Kingdom in Section V). Holiday periods for example, the last days of Ramadan in Islamic countries - are times when the

to investing advanced recently by Arnott, Hsu, and Moore (2005) and Siegel (2006).

${ }^{5}$ Lei, Noussair, and Plott (2001) generate experimental evidence showing how noise impacts bubbles, and Baker, Stein, and Wurgler (2003), Chirinko and Schaller (2001, 2006), Gilchrist, Himmelberg, and Huberman (2005), and Polk and Sapienza (2003) document the effects of equity misvaluations on investment in property, plant, and equipment. 
flow of fundamental information relevant to foreign equity markets is substantially reduced. Consequently, trading of CCEF's in U.S. markets can be responding only weakly, if at all, to fundamental information flowing from the foreign markets. CCEF return volatility during foreign holidays is thus an accurate measure of noise in the highly developed equity markets of the United States and the United Kingdom. Our approach is most closely related to the pioneering study of French and Roll (1986), who use the closing of the New York Stock Exchange on Wednesday afternoons during the second half of 1968 to separate news from noise by "turning-off" the noise channel. In contrast, the "natural experiment" afforded by foreign holidays turns-off (or tones-down) the news channel, thus allowing for a more direct estimate of equity market noise.

This paper evaluates the importance of noise by estimating return variances from three nested models of increasing generality. Section II models the return distribution for individual CCEF's as a mixture of the underlying distributions for holidays and standard days, where the former depends on the noise variance while the latter depends on both noise and information variances. The mixing variable is the exogenous occurrence of a foreign holiday. The estimation problem is simplified by the non-stochastic nature of the mixing variable, and maximum likelihood and method-of-moments estimates are equivalent. Based on 54 CCEF's traded in the United States and controlling for the effects of industry shocks and the overall U.S. market, we compute a noise ratio statistic - NR, the noise variance divided by the sum of the noise and information variances - and find that, for CCEF returns adjusted for exchange rates and the overall U.S. market, the mean of NR is 0.767 . A likelihood ratio test against the null hypothesis of a noise ratio of 0.10 is rejected at the $1 \%$ level for all 54 funds in the sample.

An attractive feature of these baseline results is that they rely on an exogenous instrument (holidays) and few modeling assumptions, thus largely 
avoiding the joint hypothesis quagmire. The only two assumptions are the normality of returns and a substantial reduction in the flow of information on holidays. Each of these assumptions is relaxed in Section III. In order to account for the kurtosis that characterizes equity returns, we replace the normal distribution underlying the baseline results with a Scaled-t distribution. The mean NR rises to 0.838 and is statistically different from a noise ratio of 0.10 at the $1 \%$ level for all 54 funds. We then allow for the possibility that some information germane to CCEF returns is nonetheless transmitted during a holiday and develop a double mixture model, where the second mixture represents the possibility of information "arrival" or "leakage" during holidays. Under this more general model, the mean NR falls to 0.759 . Formal hypothesis tests indicate that the NR is significantly far from 0.1 ; this null hypothesis is rejected at the $1 \%$ level for 51 of the 54 CCEF's and at the $5 \%$ level for all but one of the funds.

Section IV briefly examines the role of institutional owners. These financially sophisticated and patient investors are presumably less susceptible to the "sentiments" and "irrationalities" that drive noise trading. We find some support for this hypothesis, as greater institutional ownership of CCEF's is associated with less noise. This result is economically and statistically significant, and the elasticity of noise with respect to institutional ownership is about -0.15 .

Section V repeats the analysis for 32 CCEF's traded in the United Kingdom. These results provide insights into the potency of a securities transaction tax that affects trades in the United Kingdom but not in the United States. We find that the NR's for U.K. CCEF's are generally much lower than those for U.S. CCEF's. This result continues to hold when we compare U.K. to U.S. CCEF's that invest in the same country. These results provide some initial evidence that the securities 
transactions tax lowers noise volatility.

Section VI discusses several key papers that have assessed noise and its role in equity markets, and Section VII concludes.

\section{Baseline Evidence}

Our estimation strategy permits us to measure noise directly. We exploit the natural experiment produced by holidays that occur in a foreign country but that are not held at the same time in the United States. During these holiday periods, the flow of fundamental information relevant to securities in the foreign market is substantially reduced. Consequently, trading of CCEF's in the U.S. markets can be responding only weakly, if at all, to fundamental information. CCEF return volatility (with suitable adjustments discussed later in this section) during foreign holidays is thus an accurate measure of noise in the U.S. equity market.

We use a mixture model of returns and our identifying assumption to generate maximum likelihood estimates of the proportion of return variance due to noise. We assume that, in general, the CCEF return on a standard day or holiday $\left(\mathrm{R}_{\mathrm{d}, \mathrm{t}}, \mathrm{d}=\mathrm{H}, \mathrm{S}\right)$ can be decomposed into two orthogonal components due to noise $\left(\mathrm{R}_{\mathrm{t}}^{\mathrm{N}}\right)$ and information $\left(\mathrm{R}_{\mathrm{t}}^{\mathrm{I}}\right)$,

$$
\mathrm{R}_{\mathrm{d}, \mathrm{t}}=\mathrm{R}_{\mathrm{t}}^{\mathrm{N}}+\mathrm{R}_{\mathrm{t}}^{\mathrm{I}} \quad \mathrm{d}=\mathrm{H}, \mathrm{S}, \quad \forall \mathrm{t} .
$$

On standard days (non-holidays), CCEF returns are affected by both noise and information. By contrast, the identifying assumption that the information flow is largely shut-off during holidays implies that $\mathrm{R}_{\mathrm{t}}^{\mathrm{I}}$ does not affect holiday returns. Thus, $\mathrm{R}_{\mathrm{t}}$ is a mixture of distributions that apply during holidays and standard days with mixing weights determined by the occurrence of holidays, 


$$
\begin{aligned}
\mathrm{R}_{\mathrm{t}} & =\rho_{\mathrm{t}} \mathrm{R}_{\mathrm{H}, \mathrm{t}}+\left(1-\rho_{\mathrm{t}}\right) \mathrm{R}_{\mathrm{S}, \mathrm{t}} \\
& =\rho_{\mathrm{t}} \mathrm{R}_{\mathrm{t}}^{\mathrm{N}}+\left(1-\rho_{\mathrm{t}}\right)\left(\mathrm{R}_{\mathrm{t}}^{\mathrm{N}}+\mathrm{R}_{\mathrm{t}}^{\mathrm{I}}\right)
\end{aligned}
$$

where the mixing weight, $\rho_{\mathrm{t}}$, is one for holidays and zero for standard days. That the mixing weights are known and exogenous substantially simplifies the estimation problem. In this case, the likelihood function is additively separable over holidays and standard days, and the conventional maximum likelihood estimator is identical to a method of moments estimator (see the Appendix, Subsection 3). Volatility is measured in terms of variances, and the variance of the return $\left(\mathrm{V}\left[\mathrm{R}_{\mathrm{t}}\right]\right)$ during holidays $\left(\mathrm{V}_{\mathrm{H}}\right)$ and standard days $\left(\mathrm{V}_{\mathrm{S}}\right)$ is related to the noise variance $\left(\mathrm{V}^{\mathrm{N}}\right)$ and the information variance $\left(\mathrm{V}^{\mathrm{I}}\right)$ as follows,

$$
\begin{array}{ll}
\mathrm{V}\left[\mathrm{R}_{\mathrm{t}}\right] \equiv \mathrm{V}_{\mathrm{H}}=\mathrm{V}^{\mathrm{N}} & \forall \mathrm{t} \in \mathfrak{I}^{\mathrm{H}} \text { where } \mathfrak{I}^{\mathrm{H}}=\{\mathrm{t}: \mathrm{t} \text { is a holiday }\}, \\
\mathrm{V}\left[\mathrm{R}_{\mathrm{t}}\right] \equiv \mathrm{V}_{\mathrm{S}}=\mathrm{V}^{\mathrm{N}}+\mathrm{V}^{\mathrm{I}} & \forall \mathrm{t} \in \mathfrak{I}^{\mathrm{S}} \text { where } \mathfrak{I}^{\mathrm{S}}=\{\mathrm{t}: \mathrm{t} \text { is a standard day }\} .
\end{array}
$$

Note that the subscripts on $\mathrm{V}_{\mathrm{H}}$ and $\mathrm{V}_{\mathrm{S}}$ denote sample moments, while the superscripts on $\mathrm{V}^{\mathrm{N}}$ and $\mathrm{V}^{\mathrm{I}}$ denote unknown parameters entering the likelihood function. We assume that returns are distributed normal (an assumption that will be relaxed in Section III) and are mean zero (to be discussed below). The impact of noise is assessed by a noise ratio statistic, NR, defined for each CCEF as follows,

$$
\mathrm{NR} \equiv \mathrm{V}^{\mathrm{N}} /\left(\mathrm{V}^{\mathrm{N}}+\mathrm{V}^{\mathrm{I}}\right)
$$


To estimate the $\mathrm{V}^{\mathrm{N}}$ and $\mathrm{V}^{\mathrm{I}}$ parameters, we need data on foreign holidays, returns, and exchange rates. Holidays are identified by zero daily positive trading volume of a broad foreign market index (e.g. the Nikkei 225) and trading in U.S. markets. In several cases, we confirmed the accuracy of this procedure by crosschecking the holidays identified by the two criteria against the list of fixed and algorithmic holidays in Weaver (1995). Thus, holidays are when business activity and hence the flow of relevant information are substantially reduced in the foreign country.

Returns are drawn from the CRSP database on WRDS for the period beginning January 1, 1980 (or the date that the CCEF was first listed) and ending December 31, 2004 (or the date that the CCEF was delisted). CCEF's that cover more than one country (with one exception noted in Table 1) are excluded. Table 1 lists the 54 CCEF funds for the U.S. used in this study, and the table notes provide additional details about data collection.

Daily exchange rate data are obtained from Datastream and augmented where missing with exchange rate data from the Federal Reserve Bank of St. Louis.

The return series used to compute the sample moments $\left(\mathrm{V}_{\mathrm{H}}\right.$ and $\left.\mathrm{V}_{\mathrm{S}}\right)$ are adjusted for movements in exchange rates and the U.S. market. The CCEF return for a U.S. investor depends on both the net asset value (NAV) of the foreign country securities and the exchange rate into U.S. dollars. Since we are only interested in the information that affects the NAV, we subtract the log difference daily exchange rate from the CCEF return from CRSP. Hardouvelis, La Porta, and Wizman (1994, Table 8.8A) and Bodurtha, Kim, and Lee (1995, Table 8) document that CCEF returns are sensitive to the U.S. market and, to remove this effect, we estimate for each country a market model of the exchange-rate-adjusted 
CCEF return against a constant and the return on the S\&P 500. ${ }^{6}$ The residuals from this regression define the mean zero return series, $\mathrm{R}_{\mathrm{t}}$, used to compute the sample moments in equation (2), which thus are not affected by movements in exchange rates and the U.S. market. Insofar as the U.S. market return is correlated with noise in CCEF's, the use of market model residuals generates a lower bound estimate of noise.

\footnotetext{
${ }^{6}$ The constant terms ( $\alpha$ 's) are uniformly negative with a mean value of -5 basis points, and the slope coefficients ( $\beta$ 's) range from -0.130 to 1.237 with a mean value of 0.667 . The results for the market model and the noise ratios reported below are robust to defining the market return with or without dividends.
} 
Table 1: List Of U.S. Country Closed-End Funds

$\begin{array}{ll}\begin{array}{l}\text { Country } \\ \text { (1) }\end{array} & \text { Country Closed-End Fund (CCEF) } \\ \text { Argentina } & \text { Argentina Fund } \\ \text { Australia } & \text { First Australia Fund } \\ \text { Australia } & \text { Kleinwort Benson Australian Fund } \\ \text { Austria } & \text { Austria Fund } \\ \text { Brazil } & \text { Brazil Fund } \\ \text { Brazil } & \text { Brazilian Equity Fund } \\ \text { Chile } & \text { Chile Fund } \\ \text { China } & \text { China Fund } \\ \text { China } & \text { Greater China Fund } \\ \text { China } & \text { Jardine Fleming China Region Fund } \\ \text { China } & \text { Templeton China World Fund } \\ \text { Czech } & \text { Czech Republic Fund } \\ \text { France } & \text { France Fund } \\ \text { France } & \text { France Growth Fund } \\ \text { Germany } & \text { Germany Fund } \\ \text { Germany } & \text { New Germany Fund } \\ \text { Germany } & \text { Emerging Germany Fund } \\ \text { India } & \text { India Fund } \\ \text { India } & \text { India Growth Fund } \\ \text { India } & \text { Morgan Stanley India Investment Fund } \\ \text { India } & \text { Jardine Fleming India Fund } \\ \text { Indonesia } & \text { Indonesia Fund } \\ \text { Indonesia } & \text { Jakarta Growth Fund } \\ \text { Ireland } & \text { Irish Investment Fund } \\ \text { Israel } & \text { First Israel Fund } \\ & \end{array}$

Ticker

AF

IAF

KBA

OST

BZF

BZL

$\mathrm{CH}$

$\mathrm{CHN}$

$\mathrm{GCH}$

JFC

$\mathrm{TCH}$

CRF

FRN

FRF

GER

GF

FRG

IFN

IGF

IIF

JFI

IF

JGF

IRL

ISL

\section{CUSIP}

(4)

4011210

301110

26157B10

5258710

10575910

10588410

16883410

16937310

39167B10

46614T10

$88018 \mathrm{X} 10$

21923Y10

35177610

$35177 \mathrm{~K} 10$

37414310

64446510

26156W10

45408910

45409010

$61745 \mathrm{C} 10$

78657R10

45577810

47012010

64567310

$32063 \mathrm{~L} 10$
Start

(5)

12/31/1991

$12 / 26 / 1985$

$12 / 26 / 1986$

10/26/1989

$4 / 15 / 1988$

4/15/1992

10/12/1989

10/1/1992

10/1/1992

10/1/1992

10/1/1992

10/28/1994

$7 / 14 / 1986$

$5 / 24 / 1990$

$11 / 19 / 1986$

4/16/1990

4/16/1990

3/10/1994

8/15/1988

$3 / 10 / 1994$

3/10/1994

$3 / 27 / 1990$

4/26/1990

$4 / 16 / 1990$

$3 / 5 / 1993$
End $\mathbf{T}_{\mathbf{H}} \quad \mathbf{T}_{\mathbf{S}}$

(6) (7) (8)

INST

$\begin{array}{llll}12 / 14 / 2001 & 87 & 2480 & 0.237\end{array}$

$\begin{array}{llll}12 / 31 / 2004 & 63 & 4742 & 0.068\end{array}$

$\begin{array}{llll}11 / 19 / 1999 & 41 & 3244 & 0.072\end{array}$

4/26/2002 $194 \quad 2982 \quad 0.099$

12/30/2004 $213 \quad 4013 \quad 0.287$

12/30/2004 $143 \quad 3069 \quad 0.250$

12/30/2004 $131 \quad 3719 \quad 0.288$

12/31/2004 $186 \quad 2959 \quad 0.141$

12/31/2004 $186 \quad 2956 \quad 0.197$

12/31/2004 $186 \quad 2955 \quad 0.091$

$\begin{array}{llll}8 / 8 / 2003 & 160 & 2338 & 0.159\end{array}$

$\begin{array}{llll}2 / 20 / 1998 & 54 & 806 & 0.085\end{array}$

$\begin{array}{llll}12 / 8 / 1989 & 29 & 864 & 0.083\end{array}$

$\begin{array}{llll}6 / 18 / 2004 & 97 & 3459 & 0.212\end{array}$

12/30/2004 $117 \quad 4540 \quad 0.057$

12/30/2004 $91 \quad 3675 \quad 0.157$

$\begin{array}{llll}2 / 11 / 1999 & 65 & 2177 & \text { N.A. }\end{array}$

12/31/2004 $1692570 \quad 0.282$

$\begin{array}{llll}5 / 22 / 2003 & 210 & 3187 & 0.229\end{array}$

12/31/2004 $169 \quad 2567 \quad 0.274$

6/27/2003 $155 \quad 2192 \quad 0.378$

11/12/2001 $142 \quad 2811 \quad 0.132$

4/11/2000 $123 \quad 2405 \quad 0.088$

12/31/2004 $108 \quad 3613 \quad 0.193$

12/30/2004 $229 \quad 2843 \quad 0.196$ 


\begin{tabular}{|c|c|c|c|c|c|c|c|c|}
\hline Italy & Italy Fund & ITA & 46539510 & $4 / 25 / 1986$ & $2 / 13 / 2003$ & 95 & 4187 & 0.189 \\
\hline Japan & Japan Equity Fund & JEQ & 47105710 & 9/15/1992 & $12 / 30 / 2004$ & 167 & 2953 & 0.083 \\
\hline Japan & Japan Fund & JPN & 47107010 & $1 / 14 / 1980$ & 8/13/1987 & 97 & 1828 & 0.065 \\
\hline Japan & Japan OTC Equity Fund & JOF & $47109 \mathrm{U} 10$ & $3 / 20 / 1990$ & $12 / 30 / 2004$ & 200 & 3533 & 0.128 \\
\hline Korea & Fidelity Advisor Korea Fund & FAK & 31580410 & 12/29/1994 & $6 / 30 / 2000$ & 68 & 1367 & 0.108 \\
\hline Korea & Korea Fund & $\mathrm{KF}$ & 50063410 & 10/7/1987 & $12 / 30 / 2004$ & 223 & 4914 & 0.253 \\
\hline Korea & Korean Investment Fund & KIF & 50063710 & 3/10/1992 & $11 / 26 / 2001$ & 119 & 2347 & 0.200 \\
\hline Mexico & Emerging Mexico Fund & $\mathrm{MEF}$ & 29089110 & 10/12/1990 & 4/6/1999 & 73 & 2076 & 0.111 \\
\hline Mexico & Mexico Equity \& Income Fund & MXE & 59283410 & 10/12/1990 & $12 / 31 / 2004$ & 107 & 3519 & 0.201 \\
\hline Mexico & MEXICO FUND INC & MXF & 59283510 & 2/5/1990 & $12 / 31 / 2004$ & 111 & 5834 & 0.198 \\
\hline Pakistan & Pakistan Investment Fund & PKF & 69584410 & $1 / 10 / 1994$ & $6 / 22 / 2001$ & 160 & 1736 & 0.229 \\
\hline Philippines & First Philippine Fund & FPF & 33610010 & 4/9/1990 & $6 / 18 / 2003$ & 104 & 3327 & 0.131 \\
\hline South Africa & Southern Africa Fund & SOA & 84215710 & 8/9/1990 & $11 / 18 / 2004$ & 79 & 2285 & 0.322 \\
\hline South Africa & New South Africa Fund & NSA & 64880R10 & 8/9/1990 & 6/1/1999 & 30 & 958 & 0.198 \\
\hline South Africa & ASA LTD & ASA & G3156P10 & 8/9/1990 & $12 / 31 / 2004$ & 81 & 2312 & 0.216 \\
\hline Spain & Growth Fund of Spain & GSP & 39987710 & 3/19/1990 & 12/7/1998 & 111 & 2116 & 0.137 \\
\hline Spain & Spain Fund & SNF & 84633010 & 6/29/1988 & $12 / 30 / 2004$ & 183 & 3987 & 0.115 \\
\hline Switzerland & Swiss Helvetia Fund & SWZ & 87087510 & $12 / 24 / 1987$ & $12 / 30 / 2004$ & 113 & 4269 & 0.188 \\
\hline Taiwan & Taiwan Equity Fund & TYW & 87403110 & $7 / 29 / 1994$ & $5 / 5 / 2000$ & 103 & 1362 & 0.202 \\
\hline Taiwan & Taiwan Fund & TWN & 87403610 & 9/28/1987 & $12 / 31 / 2004$ & 274 & 4276 & 0.220 \\
\hline Thailand & Thai Fund & TTF & 88290410 & $3 / 2 / 1988$ & $12 / 30 / 2004$ & 230 & 4027 & 0.055 \\
\hline Thailand & Thai Capital Fund & $\mathrm{TC}$ & 88290520 & $7 / 9 / 1990$ & $2 / 6 / 2001$ & 149 & 2556 & 0.068 \\
\hline
\end{tabular}


Notes to Table 1

Data are drawn from the CRSP database on WRDS beginning 1/1/80 (or that the date the CCEF was first listed) and ending 12/31/04 (or the date that the CCEF was delisted). Closed-end funds are identified by the second digit in SHARE CODE and, from this set, CCEF's are identified by the fund name. CCEF's that cover more than one country (with one exception noted below) are excluded. Several changes occurred during the sample period: First Australia became Aberdeen Australia after 5/1/2001; Czech Fund renamed Central European Value Fund after 2/20/1998; and Jardine Fleming India became the Saffron Fund after 6/27/2003 and coverage expands to Bangladesh, Pakistan, and Sri Lanka, which constitute $10 \%$ of total fund assets. Thai Capital Fund has price $=0$ from 2/7/2001 $-12 / 26 / 2003$. $\mathrm{T}_{\mathrm{H}}$ and $\mathrm{T}_{\mathrm{S}}$ are the number of holidays and standard days, respectively. INST is the percentage of outstanding equity owned by institutions; see the notes to Table 5 for details. N.A. indicates data are not available.

Maximum likelihood estimates of NR and the underlying estimates of $\mathrm{V}^{\mathrm{N}}$ and $\mathrm{V}^{\mathrm{I}}$ with their standard errors are presented in Table 2. All estimates of $\mathrm{V}^{\mathrm{N}}$ are statistically different than zero. In the absence of noise, the NR statistic would be zero apart from sampling error. However, the NR's in column (2) are in most cases very far from zero with a mean value of 0.767 . These results are not driven by outliers and are robust to trimming $1 \%$ of the upper and lower tails ( $2 \%$ in total) of the holiday return distribution and then a similar trimming of the standard day distribution. Table 2 documents that there is a substantial amount of noise in the equity returns of CCEF's traded in the United States.

Ten of the estimated NR's are unity. This maximum value reflects a corner solution in which $\mathrm{V}^{\mathrm{I}}$ is on the boundary of zero and occurs for those CCEF's whose holiday variance exceeds the standard day variance. Since our model assigns all of the holiday variance to noise and allows noise to also affect the standard day variance, no role remains for information. These extreme situations are not problematic for tests of noise because the holiday variance exceeding the standard day variance clearly rejects the notion that noise is unimportant.

We formally evaluate the null hypothesis that the NR is 0.10 (thus allowing some noise to affect the estimates) against the maximum likelihood values in Table 
Table 2: Estimates Of Noise, Information, And The Noise Ratio

Returns Distributed Normal And Trading Volume U.S. CCEF's

\begin{tabular}{|c|c|c|c|c|c|c|c|}
\hline \multirow[b]{2}{*}{$\begin{array}{l}\text { Country Closed-End Fund (CCEF) } \\
\text { (1) }\end{array}$} & \multicolumn{6}{|c|}{ Returns } & \multirow{2}{*}{$\begin{array}{c}\text { Volume } \\
\text { NRVOL } \\
\text { (8) }\end{array}$} \\
\hline & $\begin{array}{l}\text { NR } \\
(2)\end{array}$ & $\begin{array}{l}\text { VN } \\
(3)\end{array}$ & $\begin{array}{l}\text { SE(VN) } \\
(4)\end{array}$ & $\begin{array}{l}\text { VI } \\
\text { (5) }\end{array}$ & $\begin{array}{c}\text { SE(VI) } \\
(6)\end{array}$ & $\begin{array}{l}\text { p-value } \\
\text { (7) }\end{array}$ & \\
\hline Argentina Fund & 0.515 & 2.392 & 0.363 & 2.251 & 0.386 & 0.000 & 0.468 \\
\hline First Australia & 0.744 & 2.630 & 0.469 & 0.905 & 0.474 & 0.000 & 0.528 \\
\hline Kleinwort Benson Australian Fund & 0.870 & 1.514 & 0.334 & 0.226 & 0.337 & 0.000 & 0.566 \\
\hline Austria Fund & 0.103 & 3.356 & 0.341 & 29.085 & 0.907 & 0.000 & 0.412 \\
\hline Brazil Fund & 0.953 & 5.885 & 0.570 & 0.290 & 0.587 & 0.000 & 0.487 \\
\hline Brazilan Equity Fund & 0.602 & 4.624 & 0.547 & 3.060 & 0.581 & 0.000 & 0.500 \\
\hline Chile Fund & 0.662 & 3.088 & 0.382 & 1.575 & 0.397 & 0.000 & 0.434 \\
\hline China Fund & 0.898 & 3.856 & 0.400 & 0.438 & 0.415 & 0.000 & 0.525 \\
\hline Greater China Fund & 0.775 & 3.815 & 0.396 & 1.107 & 0.416 & 0.000 & 0.519 \\
\hline Jardine Fleming China Region & 0.930 & 3.955 & 0.410 & 0.297 & 0.425 & 0.000 & 0.516 \\
\hline Templeton China World Fund & 0.672 & 2.431 & 0.272 & 1.186 & 0.292 & 0.000 & 0.451 \\
\hline Czech Republic Fund & 1.000 & 3.442 & 0.663 & 0.000 & 0.684 & 0.000 & 0.443 \\
\hline France Fund & 0.322 & 2.022 & 0.531 & 4.265 & 0.611 & 0.000 & 0.407 \\
\hline France Growth Fund & 0.751 & 1.982 & 0.285 & 0.656 & 0.292 & 0.000 & 0.430 \\
\hline Germany Fund & 0.828 & 3.746 & 0.490 & 0.779 & 0.499 & 0.000 & 0.511 \\
\hline New Germany Fund & 0.897 & 2.659 & 0.394 & 0.305 & 0.400 & 0.000 & 0.442 \\
\hline Emerging Germany Fund & 1.000 & 3.526 & 0.619 & 0.000 & 0.628 & 0.000 & 0.498 \\
\hline India Fund & 0.583 & 2.807 & 0.305 & 2.004 & 0.334 & 0.000 & 0.495 \\
\hline India Growth Fund & 0.827 & 3.947 & 0.240 & 0.828 & 0.268 & 0.000 & 0.459 \\
\hline Morgan Stanley India & 0.640 & 3.180 & 0.346 & 1.786 & 0.373 & 0.000 & 0.510 \\
\hline Jardine Fleming India & 0.543 & 2.625 & 0.298 & 2.210 & 0.332 & 0.000 & 0.475 \\
\hline Indonesia Fund & 0.906 & 10.065 & 1.195 & 1.044 & 1.231 & 0.000 & 0.497 \\
\hline Jakarta Growth Fund & 0.719 & 6.496 & 0.828 & 2.533 & 0.868 & 0.000 & 0.501 \\
\hline Irish Investment Fund & 1.000 & 4.477 & 0.609 & 0.000 & 0.618 & 0.000 & 0.522 \\
\hline First Israel Fund & 0.685 & 2.028 & 0.190 & 0.933 & 0.205 & 0.000 & 0.411 \\
\hline Italy Fund & 0.525 & 2.525 & 0.366 & 2.282 & 0.381 & 0.000 & 0.426 \\
\hline Japan Equity Fund & 0.888 & 3.640 & 0.398 & 0.461 & 0.412 & 0.000 & 0.498 \\
\hline Japan Fund & 1.000 & 4.097 & 0.588 & 0.000 & 0.604 & 0.000 & 0.481 \\
\hline Japan OTC Equity Fund & 0.724 & 4.372 & 0.437 & 1.668 & 0.460 & 0.000 & 0.489 \\
\hline Fidelity Korea Fund & 0.798 & 5.376 & 0.922 & 1.363 & 0.957 & 0.000 & 0.540 \\
\hline Korea Fund & 0.772 & 6.509 & 0.616 & 1.921 & 0.639 & 0.000 & 0.518 \\
\hline Korean Investment Fund & 0.705 & 4.759 & 0.617 & 1.995 & 0.648 & 0.000 & 0.508 \\
\hline Korea Equity Fund & 0.994 & 5.880 & 0.698 & 0.033 & 0.716 & 0.000 & 0.537 \\
\hline Malaysia Fund & 0.930 & 6.762 & 0.683 & 0.506 & 0.701 & 0.000 & 0.478 \\
\hline Emerging Mexico Fund & 0.615 & 3.999 & 0.662 & 2.498 & 0.692 & 0.000 & 0.455 \\
\hline Mexico Equity and Income & 0.576 & 2.609 & 0.357 & 1.923 & 0.373 & 0.000 & 0.440 \\
\hline Mexico Fund & 0.311 & 2.485 & 0.334 & 5.498 & 0.365 & 0.000 & 0.509 \\
\hline Pakistan Investment Fund & 0.758 & 6.175 & 0.690 & 1.969 & 0.744 & 0.000 & 0.502 \\
\hline First Philippine Fund & 1.000 & 6.557 & 0.909 & 0.000 & 0.923 & 0.000 & 0.468 \\
\hline Portugal Fund & 0.705 & 2.535 & 0.316 & 1.063 & 0.331 & 0.000 & 0.496 \\
\hline Templeton Russia Fund & 0.938 & 9.173 & 1.156 & 0.602 & 1.192 & 0.000 & 0.460 \\
\hline
\end{tabular}




\begin{tabular}{|c|c|c|c|c|c|c|c|}
\hline Singapore Fund & 0.522 & 1.981 & 0.283 & 1.817 & 0.297 & 0.000 & 0.488 \\
\hline Southern Africa Fund & 0.990 & 2.547 & 0.405 & 0.025 & 0.412 & 0.000 & 0.478 \\
\hline New South Africa Fund & 0.400 & 1.052 & 0.272 & 1.576 & 0.297 & 0.000 & 0.387 \\
\hline ASA Ltd & 1.000 & 6.133 & 0.964 & 0.000 & 0.980 & 0.000 & 0.500 \\
\hline Growth Fund of Spain & 0.890 & 2.409 & 0.323 & 0.298 & 0.334 & 0.000 & 0.459 \\
\hline Spain Fund & 1.000 & 5.000 & 0.523 & 0.000 & 0.535 & 0.000 & 0.462 \\
\hline Swiss Helvetia Fund & 0.581 & 1.904 & 0.253 & 1.372 & 0.263 & 0.000 & 0.504 \\
\hline Taiwan Equity Fund & 0.944 & 3.278 & 0.457 & 0.195 & 0.476 & 0.000 & 0.423 \\
\hline Taiwan Fund & 1.000 & 9.999 & 0.854 & 0.000 & 0.881 & 0.000 & 0.515 \\
\hline Thai Fund & 0.786 & 5.978 & 0.557 & 1.628 & 0.583 & 0.000 & 0.480 \\
\hline Thai Capital Fund & 1.000 & 8.820 & 1.022 & 0.000 & 1.051 & 0.000 & 0.486 \\
\hline Turkish Investment Fund & 0.651 & 6.206 & 0.726 & 3.329 & 0.760 & 0.000 & 0.489 \\
\hline United Kingdom Fund & 1.000 & 4.445 & 0.927 & 0.000 & 0.934 & 0.000 & 0.489 \\
\hline Mean & 0.767 & & & & & & 0.481 \\
\hline Median & 0.781 & & & & & & 0.489 \\
\hline
\end{tabular}

Notes to Table 2

See Notes to Table 1 for details about the data. The noise ratio for returns (NR) in column (2) is computed according to equation (4) for U.S. CCEF's. Returns are assumed to be distributed normal and are adjusted for exchange rates and the U.S. market return as discussed in Section II. $\mathrm{V}^{\mathrm{N}}$ and $\mathrm{V}^{\mathrm{I}}$ are maximum likelihood estimates, which are equivalent to method of moments estimates under the assumptions used to construct the estimates in this table. Standard errors (SE) are computed as follows: $\mathrm{SE}\left[\mathrm{V}^{\mathrm{N}}\right]=\left\{\left(2 / \mathrm{T}_{\mathrm{H}}\right)^{*} \mathrm{~V}_{\mathrm{H}}\right\}^{(1 / 2)}$ and $\mathrm{SE}\left[\mathrm{V}^{\mathrm{I}}\right]=\left\{\left(2 / \mathrm{T}_{\mathrm{H}}\right)^{*} \mathrm{~V}_{\mathrm{H}}{ }^{2}+\right.$ $\left.\left(2 / \mathrm{T}_{\mathrm{S}}\right) * \mathrm{~V}_{\mathrm{S}}{ }^{2}\right\}^{(1 / 2)}$. The values of $\mathrm{V}^{\mathrm{N}}, \mathrm{V}^{\mathrm{I}}$, and the SE's reported in Table 2 are multiplied by $10^{4}$. Column (7) contains the $p$-value for evaluating the null hypothesis that $\mathrm{NR}=0.10$. The noise ratio for volume ( $\mathrm{NR}^{\mathrm{VOL}}$ ) in column (8) is computed according to equation (5) for U.S. CCEF's.

2. ${ }^{7}$ Details of this likelihood ratio test are presented in Section 4 of the Appendix. Hypothesis tests indicate that the NR's are very far from 0.10 ; the null hypothesis is rejected at the $1 \%$ level for all 54 funds.

Complementary evidence is provided by examining trading volume on holiday and standard days. In this case, the noise ratio statistic, $\mathrm{NR}^{\mathrm{VOL}}$, is defined in terms of the first moment of trading volume,

$$
\mathrm{NR}^{\mathrm{VOL}} \equiv \mathrm{VOL}^{\mathrm{N}} /\left(\mathrm{VOL}^{\mathrm{N}}+\mathrm{VOL}^{\mathrm{I}}\right)
$$

\footnotetext{
${ }^{7}$ Under certain conditions, NR is distributed Cauchy, which has neither a mean nor variance, and therefore NR can not be evaluated with a Wald test.
} 
where $\mathrm{VOL}^{\mathrm{N}}$ is trading volume due to noise measured by mean trading volume on holidays and $\mathrm{VOL}^{\mathrm{I}}$ is trading volume due to information measured by mean trading volume on standard days less $\mathrm{VOL}^{\mathrm{N}}$ (cf. equations (3) substituting VOL for V). As with the return-based NR's, $\mathrm{NR}^{\mathrm{VOL}}$ is far from zero. The mean value of the $\mathrm{NR}^{\mathrm{VOL}}$ 's displayed in column (7) is 0.481 .

There are several attractive features of our estimation strategy. The holiday instrument is clearly exogenous and independent of noise in U.S. equity markets, and the factors that contribute to closed-end fund discounts do not vary at a daily frequency. Informed trading might occur during holidays as U.S. investors rebalance their portfolios; however, the well-known home bias of equity portfolios vastly diminishes the quantitative importance of rebalancing. The results in Table 2 rely on few modeling assumptions and thus largely avoid the joint hypothesis quagmire. The only two assumptions are the normality of returns -- to be relaxed in Section III.A -- and the substantial reduction in the flow of information on holidays.

The estimation strategy adopted in this paper rests on the latter identifying assumption. Even if a foreign country is closed for business, the fortunes of its companies might be buffeted by industry or global shocks emanating from outside the country. Industry shocks will not compromise our results because they will be dissipated over the portfolio of stocks constituting the CCEF's. Global shocks will in large part be accounted for by the market model, as the U.S. return will capture both the effects of the U.S. market and that part of the global shock correlated with the U.S. market. The residual global shock is accounted for in two ways. First, insofar as global shocks are large and infrequent, their impact is eliminated by trimming the tails of the distributions. Second, the impact of whatever fundamental global (or industry) information remains will be captured by the 
double mixture model of returns that allows for information leakage and that will be discussed in Section III.B.

\section{Refinements}

\section{A. Kurtosis}

The variance estimates in Table 2 are based on the assumption that the returns are distributed normal. Given the well documented kurtosis in equity returns (e.g., Campbell, Lo, and MacKinlay, 1997, Table 1.1), variance estimates in the numerator and denominator of NR may be biased. A parsimonious way for addressing this problem is to assume that CCEF returns are distributed Scaled-t. ${ }^{8}$ Under this more general assumption, the log likelihood depends on a variance parameter and a "degrees-of-freedom" parameter, $k>2$. For values of $k \geq 30$, the Scaled-t distribution converges to the normal distribution used in the previous section. Since the Scaled-t distribution introduces higher order even moments, multiple solutions exist for $\mathrm{V}^{\mathrm{N}}$ and $\mathrm{V}^{\mathrm{I}}$ estimated by the method of moments. ${ }^{9}$ To avoid this multiplicity problem, we evaluate the log likelihood function with a grid search over the parameter vector $\Psi=\left\{\mathrm{V}^{\mathrm{N}}, \mathrm{V}^{\mathrm{I}}, \mathrm{k}\right\}$. A grid search also allows us to

\footnotetext{
standard days is as follows,

$$
\begin{aligned}
\mathrm{f}\left(\mathrm{R}_{\mathrm{t}} ; \mathrm{V}^{\mathrm{N}}+\mathrm{V}^{\mathrm{I}}, \mathrm{k}\right)= & \left\{\Gamma((\mathrm{k}+1) / 2) /\left(\Gamma(\mathrm{k} / 2)\left(\pi(\mathrm{k}-2)\left(\mathrm{V}^{\mathrm{N}}+\mathrm{V}^{\mathrm{I}}\right)\right)^{\frac{1}{2}}\right)\right\} \\
& \left\{\left[1+\left(\mathrm{R}_{\mathrm{t}}^{2} /\left((\mathrm{k}-2)\left(\mathrm{V}^{\mathrm{N}}+\mathrm{V}^{\mathrm{I}}\right)\right)\right)\right]^{-((\mathrm{k}+1) / 2)}\right\}
\end{aligned}
$$
}

${ }^{8}$ Focusing on unconditional volatility with the Scaled-t distribution requires fewer modeling choices than GARCH modeling of conditional volatility. Praetz (1972) links a fluctuating return variance to the Scaled-t distribution. The density function for the Scaled-t distribution for

where $\mathrm{k}$ is the degrees of freedom parameter and $\Gamma($.$) is the gamma function. This density$ characterizes returns on holidays when $\mathrm{V}^{\mathrm{I}}=0$.

${ }^{9}$ We thank Nicholas Kiefer for this observation that led us to maximum likelihood estimation. 
avoid using incorrect estimates defined by a local maximum. ${ }^{10}$ The parameter space is determined by the admissible values in equation $(3): V^{\mathrm{N}}=\left\{(1 / \mathrm{m}) \mathrm{V}_{\mathrm{H}}\right.$, $\left.(2 / \mathrm{m}) \mathrm{V}_{\mathrm{H}}, \ldots, \mathrm{V}_{\mathrm{H}}\right\}, \mathrm{V}^{\mathrm{I}}=\left\{(1 / \mathrm{m}) \mathrm{V}_{\mathrm{S}},(2 / \mathrm{m}) \mathrm{V}_{\mathrm{S}}, \ldots, \mathrm{V}_{\mathrm{S}}\right\}, \mathrm{k}=\{3,4, \ldots, 30\}$, where the parameter determining the size of the increments is $\mathrm{m}=400$.

Table 3 contains maximum likelihood estimates with the Scaled-t distribution. Estimates of $\mathrm{k}$ range from 3 to 6 with a mode of 4 . These estimates are very far from the value of $\mathrm{k}=30$ that corresponds to a normality assumption and suggest the importance of accounting for fat-tails in the return distribution. ${ }^{11}$ Relative to assuming normality in Table 2, we find that the $\mathrm{V}^{\mathrm{N}}$, s tend to rise modestly and the $\mathrm{V}^{\mathrm{I}}$, s decline more sharply. The percentage changes in the means of $\mathrm{V}^{\mathrm{N}}$ and $\mathrm{V}^{\mathrm{I}}$ are $+5.5 \%$ and $-22.7 \%$, respectively (excluding the large observation for the Austria Fund). The mean value of NR rises 9.3\% from 0.767 in Table 2 to 0.838 in Table 3 . Our conclusion that CCEF returns are largely influenced by noise is insensitive to kurtosis.

\section{B. A Double Mixture Model Of Returns}

The above estimates have been based on the assumption that, on foreign holidays, the flow of information relevant for pricing CCEF's is totally eliminated. Nonetheless, it is not unreasonable to assume that -- despite our adjustments for industry and global shocks, exchange rates, and the U.S. overall market -- some information germane to CCEF returns is transmitted during a holiday. This subsection generalizes the previous models by allowing for the possibility of information "arrival" or "leakage" during holidays.

\footnotetext{
${ }^{10}$ The possibility of settling at a local maximum or encountering other estimation problems with an ill-behaved likelihood function (Hamilton, 1994, p. 689) will be exacerbated in the double mixture model discussed in Section III.B.

${ }^{11}$ Similar results for $\mathrm{k}$ are obtained by Aparicio and Estrada (2001) for daily aggregate return indices of 13 European equity markets.
} 


\section{Table 3: Estimates Of Noise, Information, And The Noise Ratio Returns Distributed Scaled-t U.S. CCEF's}

\begin{tabular}{|c|c|c|c|c|c|}
\hline $\begin{array}{l}\text { Country Closed-End Fund (CCEF) } \\
\text { (1) }\end{array}$ & $\begin{array}{l}\text { NR } \\
(2)\end{array}$ & $\begin{array}{l}V^{N} \\
(3)\end{array}$ & $\begin{array}{l}v^{\prime} \\
(4)\end{array}$ & $\begin{array}{c}k \\
(5)\end{array}$ & $\begin{array}{c}\text { p-value } \\
(6)\end{array}$ \\
\hline Argentina Fund & 0.682 & 3.181 & 1.486 & 4 & 0.000 \\
\hline First Australia & 0.977 & 3.025 & 0.071 & 4 & 0.000 \\
\hline Kleinwort Benson Australian Fund & 0.938 & 1.560 & 0.104 & 6 & 0.000 \\
\hline Austria Fund & 0.767 & 4.263 & 1.298 & 3 & 0.000 \\
\hline Brazil Fund & 0.897 & 5.355 & 0.618 & 4 & 0.000 \\
\hline Brazilian Equity Fund & 0.746 & 5.410 & 1.844 & 4 & 0.000 \\
\hline Chile Fund & 0.672 & 2.871 & 1.399 & 3 & 0.000 \\
\hline China Fund & 0.871 & 4.049 & 0.601 & 4 & 0.000 \\
\hline Greater China Fund & 0.920 & 4.540 & 0.394 & 4 & 0.000 \\
\hline Jardine Fleming China Region & 0.959 & 3.995 & 0.170 & 5 & 0.000 \\
\hline Templeton China World Fund & 0.784 & 2.893 & 0.796 & 5 & 0.000 \\
\hline Czech Republic Fund & 1.000 & 2.926 & 0.000 & 4 & 0.000 \\
\hline France Fund & 0.838 & 3.255 & 0.629 & 4 & 0.000 \\
\hline France Growth Fund & 0.795 & 2.042 & 0.528 & 5 & 0.000 \\
\hline Germany Fund & 0.819 & 4.084 & 0.905 & 3 & 0.000 \\
\hline New Germany Fund & 1.000 & 2.845 & 0.000 & 4 & 0.000 \\
\hline Emerging Germany Fund & 1.000 & 3.279 & 0.000 & 5 & 0.000 \\
\hline India Fund & 0.639 & 3.060 & 1.732 & 6 & 0.000 \\
\hline India Growth Fund & 0.881 & 4.934 & 0.669 & 3 & 0.000 \\
\hline Morgan Stanley India & 0.763 & 3.848 & 1.192 & 5 & 0.000 \\
\hline Jardine Fleming India & 0.544 & 2.652 & 2.224 & 5 & 0.000 \\
\hline Indonesia Fund & 1.000 & 11.978 & 0.000 & 3 & 0.000 \\
\hline Jakarta Growth Fund & 0.931 & 9.809 & 0.722 & 3 & 0.000 \\
\hline Irish Investment Fund & 1.000 & 2.373 & 0.000 & 4 & 0.000 \\
\hline First Israel Fund & 0.760 & 2.252 & 0.711 & 4 & 0.000 \\
\hline Italy Fund & 0.830 & 4.216 & 0.865 & 3 & 0.000 \\
\hline Japan Equity Fund & 0.960 & 3.895 & 0.164 & 5 & 0.000 \\
\hline Japan Fund & 1.000 & 3.073 & 0.000 & 4 & 0.000 \\
\hline Japan OTC Equity Fund & 0.822 & 5.027 & 1.087 & 5 & 0.000 \\
\hline Fidelity Korea Fund & 0.716 & 5.107 & 2.021 & 4 & 0.000 \\
\hline Korea Fund & 0.836 & 5.142 & 1.012 & 4 & 0.000 \\
\hline Korean Investment Fund & 0.762 & 5.187 & 1.621 & 4 & 0.000 \\
\hline Korea Equity Fund & 1.000 & 6.056 & 0.000 & 6 & 0.000 \\
\hline Malaysia Fund & 0.928 & 7.506 & 0.581 & 3 & 0.000 \\
\hline Emerging Mexico Fund & 0.713 & 4.519 & 1.819 & 4 & 0.000 \\
\hline Mexico Equity and Income & 0.759 & 3.991 & 1.269 & 3 & 0.000 \\
\hline Mexico Fund & 0.417 & 3.653 & 5.109 & 3 & 0.000 \\
\hline Pakistan Investment Fund & 0.714 & 6.113 & 2.443 & 4 & 0.000 \\
\hline First Philippine Fund & 0.981 & 5.442 & 0.106 & 4 & 0.000 \\
\hline Portugal Fund & 0.947 & 3.828 & 0.216 & 3 & 0.000 \\
\hline Templeton Russia Fund & 0.744 & 9.081 & 3.128 & 3 & 0.000 \\
\hline Singapore Fund & 0.623 & 2.515 & 1.519 & 4 & 0.000 \\
\hline Southern Africa Fund & 0.715 & 2.063 & 0.823 & 3 & 0.000 \\
\hline
\end{tabular}




$\begin{array}{llllll}\text { New South Africa Fund } & 0.574 & 1.630 & 1.209 & 3 & 0.000 \\ \text { ASA Ltd } & 1.000 & 6.440 & 0.000 & 3 & 0.000 \\ \text { Growth Fund of Spain } & 0.858 & 2.288 & 0.379 & 5 & 0.000 \\ \text { Spain Fund } & 1.000 & 5.451 & 0.000 & 3 & 0.000 \\ \text { Swiss Helvetia Fund } & 0.951 & 2.532 & 0.131 & 3 & 0.000 \\ \text { Taiwan Equity Fund } & 0.785 & 2.787 & 0.764 & 5 & 0.000 \\ \text { Taiwan Fund } & 0.836 & 6.100 & 1.200 & 3 & 0.000 \\ \text { Thai Fund } & 0.862 & 8.548 & 1.369 & 3 & 0.000 \\ \text { Thai Capital Fund } & 0.968 & 9.261 & 0.302 & 3 & 0.000 \\ \text { Turkish Investment Fund } & 0.751 & 6.889 & 2.288 & 5 & 0.000 \\ \text { United Kingdom Fund } & 1.000 & 2.445 & 0.000 & 5 & 0.000 \\ & & & & & \end{array}$

Notes to Table 3

See Notes to Table 1 for details about the data. The noise ratio for returns (NR) in column (2) is computed according to equation (4) for U.S. CCEF's. Returns are assumed to be distributed Scaled-t as described in $\mathrm{fn}$. 8. The parameters $\left\{\mathrm{V}^{\mathrm{N}}, \mathrm{V}^{\mathrm{I}}, \mathrm{k}\right\}$ are estimated by maximum likelihood based on a grid search: the parameter space is determined by the admissible values in equation (3): $\mathrm{V}^{\mathrm{N}}=\left\{(1 / \mathrm{m}) \mathrm{V}_{\mathrm{H}},(2 / \mathrm{m}) \mathrm{V}_{\mathrm{H}}, \ldots, \mathrm{V}_{\mathrm{H}}\right\}, \mathrm{V}^{\mathrm{I}}=\left\{(1 / \mathrm{m}) \mathrm{V}_{\mathrm{S}},(2 / \mathrm{m}) \mathrm{V}_{\mathrm{S}}, \ldots, \mathrm{V}_{\mathrm{S}}\right\}, \mathrm{k}=\{3,4, \ldots, 30\}$, where the parameter determining the size of the increments is $\mathrm{m}=400$. When $\mathrm{k}$ equals 30 , the Scaled-t distribution approximates a normal distribution. The values of $\mathrm{V}^{\mathrm{N}}$ and $\mathrm{V}^{\mathrm{I}}$ reported in Table 3 are multiplied by $10^{4}$. Column (6) contains the p-value for evaluating the null hypothesis that $\mathrm{NR}=0.10$.

CCEF returns are modeled as a double mixture. ${ }^{12}$ We assume that the probability of information "arrival" or "leakage" during holidays is non-negative and represented by a parameter, $0 \leq \lambda \leq 0.5$, the probability of information arrival. The importance of information (and thus the volatility due to information) for holiday returns is influenced by the value of $\lambda$. In this case, the holiday return in equation (1) is replaced by the following mixture of noise and information returns,

$$
\begin{aligned}
\mathrm{R}_{\mathrm{H}, \mathrm{t}} & =\mathrm{R}_{\mathrm{t}}^{\mathrm{N}}+\delta_{\mathrm{t}} \mathrm{R}_{\mathrm{t}}^{\mathrm{I}} \quad \forall \mathrm{t} \in \mathfrak{J}^{\mathrm{H}} \text { where } \mathfrak{J}^{\mathrm{H}}=\{\mathrm{t}: \mathrm{t} \text { is a holiday }\} \\
& =\left(1-\delta_{\mathrm{t}}\right) \mathrm{R}_{\mathrm{t}}^{\mathrm{N}}+\delta_{\mathrm{t}}\left(\mathrm{R}_{\mathrm{t}}^{\mathrm{N}}+\mathrm{R}_{\mathrm{t}}^{\mathrm{I}}\right),
\end{aligned}
$$

\footnotetext{
12 See Hamilton (1994, Section 22.3) and McLachlan and Peel (2000, Chapter 1) for overviews of mixture models. Roll (1988, Section IV.A) uses a formulation similar to equation (6).
} 
where the stochastic mixing weight, $\delta_{t}$, equals 1 if information arrives on a given day, is 0 otherwise, and is distributed Bernoulli with mean $\lambda$. The second line in equation (6) highlights how $\delta_{t}$ is a mixing weight for noise and noise plus information. Allowing for information leakage during holidays does not affect the equation for standard days (equation (1) with $\mathrm{d}=\mathrm{S}$ ). The double mixture model combines the returns from holidays and standard days and, for each of these types of days, combines the returns from noise and news,

$$
\begin{aligned}
& \mathrm{R}_{\mathrm{t}}=\rho_{\mathrm{t}} \mathrm{R}_{\mathrm{H}, \mathrm{t}}+\left(1-\rho_{\mathrm{t}}\right) \mathrm{R}_{\mathrm{S}, \mathrm{t}} \\
& \mathrm{R}_{\mathrm{t}}=\rho_{\mathrm{t}}\left(\left(1-\delta_{\mathrm{t}}\right) \mathrm{R}_{\mathrm{t}}^{\mathrm{N}}+\delta_{\mathrm{t}}\left(\mathrm{R}_{\mathrm{t}}^{\mathrm{N}}+\mathrm{R}_{\mathrm{t}}^{\mathrm{I}}\right)\right)+\left(1-\rho_{\mathrm{t}}\right)\left(\mathrm{R}_{\mathrm{t}}^{\mathrm{N}}+\mathrm{R}_{\mathrm{t}}^{\mathrm{I}}\right)
\end{aligned} \quad \forall \mathrm{t},
$$

In general, analyzing this double mixture model would be very difficult. However, in our case, one of the mixing variable $\left(\rho_{t}\right)$ is non-stochastic, and the estimation problem becomes considerably more tractable. The log likelihood function is evaluated with a grid search over the parameter vector $\Psi=\left\{\mathrm{V}^{\mathrm{N}}, \mathrm{V}^{\mathrm{I}}, \mathrm{k}, \lambda\right\}$ for the same parameter space as used for the Scaled-t model for the first three parameters. In addition, we allow $\lambda=\{0.1,0.2, \ldots, 0.5\}$, reflecting the possibility that there is some information flow during holidays.

Imposing the Scaled-t distributions for $\mathrm{V}^{\mathrm{N}}$ and $\mathrm{V}^{\mathrm{I}}$ is important for proper inferences to be drawn from the double mixture model. A possible difficulty with using equations (6) or (7) to quantify noise is that the estimated $\lambda$ may be influenced by return kurtosis. If the underlying returns were assumed normal, a high value of $\lambda$ could be due to information flow during holidays or to the kurtotic distribution of returns captured by a mixture of two normals (Press, 1967; McLachlan and Peel, 2000, Section 1.5). By assuming that $\mathrm{V}^{\mathrm{N}}$ and $\mathrm{V}^{\mathrm{I}}$ are distributed Scaled-t, we allow $\lambda$ greater scope for capturing information flows. 
Parameter estimates for the double mixture model presented in Table 4 confirm the importance of noise. All but three of the NR's are above 0.40. As expected, the role of noise is diminished in this model that allows some of the holiday return volatility to be accounted for by information. The mean NR of 0.759 is lower than the mean NR of 0.838 (Table 3) for the Scaled-t model without leakage.

We formally evaluate the null hypothesis that the NR is 0.10 (thus allowing some noise to affect the estimates) against the maximum likelihood values in Table 4. As indicated by the p-values in column 7 , this null hypothesis is rejected at the $1 \%$ level for 51 of the 54 CCEF's and at the $5 \%$ level for all but one fund. Noise continues to be an important component of return volatility even when there is information leakage during holidays.

\section{Institutional Ownership}

The results in Table 4 provide some evidence that the source of noise is not related to characteristics of the non-U.S. markets in which the CCEF's underlying assets are located. Several countries have more than one CCEF. For Brazil, France, and Thailand, the NR's within a country are fairly close together. More dispersion exists for other countries. For example, The Emerging Mexico Fund and the Mexico Equity and Income CCEF's have NR's of 0.721 and 0.759, respectively; these NR's are much higher than the value of 0.399 for the Mexico Fund. Given this variety, country characteristics are unlikely to explain the variation in the NR's.

Noise thus appears to be driven by the trading environment in U.S. equity markets or the nature of CCEF investors. The role of the trading environment will be explored in Section V by drawing comparisons between U.S. and U.K. CCEF's. Here we investigate the role of institutional ownership, which is a salient investor 


\section{Table 4: Estimates Of Noise, Information, And The Noise Ratio Returns Distributed Scaled-t Information Affects Holiday Returns $(\lambda \geq 0)$ U.S. CCEF's}

Country Closed-End Fund (CCEF)

(1)

Argentina Fund

First Australia

Kleinwort Benson Australian Fund

Austria Fund

Brazil Fund

Brazilian Equity Fund

Chile Fund

China Fund

Greater China Fund

Jardine Fleming China Region

Templeton China World Fund

Czech Republic Fund

France Fund

France Growth Fund

Germany Fund

New Germany Fund

Emerging Germany Fund

India Fund

India Growth Fund

Morgan Stanley India

Jardine Fleming India

Indonesia Fund

Jakarta Growth Fund

Irish Investment Fund

First Israel Fund

Italy Fund

Japan Equity Fund

Japan Fund

Japan OTC Equity Fund

Fidelity Korea Fund

Korea Fund

Korean Investment Fund

Korea Equity Fund

Malaysia Fund

Emerging Mexico Fund

Mexico Equity and Income

Mexico Fund
NR

(2)

0.682

0.977

0.009

0.535

0.713

0.746

0.672

0.759

0.920

0.919

0.784

1.000

0.838

0.752

0.621

1.000

1.000

0.639

0.779

0.763

0.404

1.000

0.931

1.000

0.760

0.830

0.960

1.000

0.822

0.232

0.644

0.762

1.000

0.906

0.721

0.759

0.399
$\mathbf{V}^{\mathrm{N}}$

(3)

$\mathbf{V}^{\prime}$

(4)

3.181

3.025

0.015

2.987

4.296

5.410

2.871

3.509

4.540

3.837

2.893

2.926

3.255

1.923

3.110

2.845

3.279

3.060

4.382

3.848

1.969

11.978

9.809

2.373

2.252

4.216

3.895

3.073

5.027

1.666

3.970

5.187

6.056

5.613

6.038

3.991

2.758
1.486

0.071

1.671

2.595

1.729

1.844

1.399

1.117

0.394

0.340

0.796

0.000

0.629

0.633

1.901

0.000

0.000

1.732

1.242

1.192

2.901

0.000

0.722

0.000

0.711

0.865

0.164

0.000

1.087

5.525

2.192

1.621

0.000

0.581

2.339

1.269

4.151 k

(5)

$\lambda$

p-value

(7)

$\begin{array}{lrl}4 & 0 & 0.000 \\ 4 & 0.5 & 0.000 \\ 6 & 0.5 & 0.000 \\ 3 & 0.5 & 0.000 \\ 4 & 0.5 & 0.000 \\ 4 & 0 & 0.000 \\ 3 & 0 & 0.000 \\ 4 & 0.5 & 0.000 \\ 4 & 0 & 0.000 \\ 5 & 0.5 & 0.000 \\ 5 & 0 & 0.000\end{array}$

4

4

4

5

3

4

4
5

5
6

6

5

5

3

3
3

4

4
4

3
5

5

4

4
5

5
4

4

6

4

6
3

4

4
3

3
3

$\begin{array}{ll}0 & 0.000\end{array}$

$0 \quad 0.000$

$\begin{array}{ll}0.1 & 0.000\end{array}$

$0.5 \quad 0.000$

$0.1 \quad 0.000$

$0.3 \quad 0.000$

$0 \quad 0.000$

$0.5 \quad 0.000$

$0 \quad 0.000$

$0.3 \quad 0.000$

$0.4 \quad 0.000$

$\begin{array}{ll}0 & 0.000\end{array}$

$0.5 \quad 0.000$

$0 \quad 0.000$

$0 \quad 0.000$

$0.1 \quad 0.000$

$0.1 \quad 0.000$

$0 \quad 0.000$

$0.5 \quad 0.200$

$0.5 \quad 0.000$

$0 \quad 0.000$

$0.3 \quad 0.000$

$0 \quad 0.000$

$0 \quad 0.000$

$0 \quad 0.000$

$0 \quad 0.008$ 


$\begin{array}{lllllrl}\text { Pakistan Investment Fund } & 0.411 & 3.520 & 5.049 & 4 & 0.5 & 0.048 \\ \text { First Philippine Fund } & 0.957 & 7.016 & 0.317 & 4 & 0.3 & 0.000 \\ \text { Portugal Fund } & 0.947 & 3.828 & 0.216 & 3 & 0.2 & 0.000 \\ \text { Templeton Russia Fund } & 0.439 & 4.128 & 5.278 & 3 & 0.5 & 0.000 \\ \text { Singapore Fund } & 0.629 & 3.347 & 1.975 & 4 & 0 & 0.009 \\ \text { Southern Africa Fund } & 0.484 & 1.401 & 1.492 & 3 & 0.5 & 0.002 \\ \text { New South Africa Fund } & 0.574 & 1.630 & 1.209 & 3 & 0 & 0.024 \\ \text { ASA Ltd } & 1.000 & 4.600 & 0.000 & 3 & 0.4 & 0.000 \\ \text { Growth Fund of Spain } & 0.577 & 2.288 & 1.678 & 5 & 0.5 & 0.002 \\ \text { Spain Fund } & 1.000 & 4.150 & 0.000 & 3 & 0.5 & 0.000 \\ \text { Swiss Helvetia Fund } & 0.964 & 1.770 & 0.066 & 3 & 0.1 & 0.000 \\ \text { Taiwan Equity Fund } & 0.527 & 2.787 & 2.501 & 5 & 0.5 & 0.000 \\ \text { Taiwan Fund } & 0.671 & 4.900 & 2.400 & 3 & 0.5 & 0.000 \\ \text { Thai Fund } & 0.830 & 8.189 & 1.673 & 3 & 0.2 & 0.000 \\ \text { Thai Capital Fund } & 0.978 & 6.615 & 0.151 & 3 & 0.5 & 0.000 \\ \text { Turkish Investment Fund } & 0.755 & 7.633 & 2.479 & 5 & 0 & 0.000 \\ \text { United Kingdom Fund } & 1.000 & 2.712 & 0.000 & 5 & 0.5 & 0.000 \\ & & & & & & \end{array}$

Notes to Table 4

See Notes to Table 1 for details about the data. The noise ratio for returns (NR) in column (2) is computed according to equation (4) for U.S. CCEF's. Returns are assumed to be distributed Scaled$\mathrm{t}$ as described in $\mathrm{fn} .8$, and information affects $\mathrm{V}_{\mathrm{H}}$ per equation (7). The parameters $\left\{\mathrm{V}^{\mathrm{N}}, \mathrm{V}^{\mathrm{I}}, \mathrm{k}, \lambda\right\}$ are estimated by maximum likelihood based on a grid search: the parameter space is determined by the admissible values in equation (3): $\mathrm{V}^{\mathrm{N}}=\left\{(1 / \mathrm{m}) \mathrm{V}_{\mathrm{H}},(2 / \mathrm{m}) \mathrm{V}_{\mathrm{H}}, \ldots, \mathrm{V}_{\mathrm{H}}\right\}, \mathrm{V}^{\mathrm{I}}=\left\{(1 / \mathrm{m}) \mathrm{V}_{\mathrm{S}},(2 / \mathrm{m}) \mathrm{V}_{\mathrm{S}}, \ldots, \mathrm{V}_{\mathrm{S}}\right\}, \mathrm{k}$ $=\{3,4, \ldots, 30\} \lambda=\{0.1,0.1, \ldots, 0.5\}$, where the parameter determining the size of the increments is $\mathrm{m}=$ 400. When k equals 30, the Scaled-t distribution approximates a normal distribution. The values of $\mathrm{V}^{\mathrm{N}}$ and $\mathrm{V}^{\mathrm{I}}$ reported in Table 4 are multiplied by $10^{4}$. Column (7) contains the p-value for evaluating the null hypothesis that $\mathrm{NR}=0.10$.

characteristic that presumably identifies financially sophisticated and patient owners less susceptible to the "sentiments" that drive noise trading. We would thus expect the NR's to be negatively related to the percentage of equity held by institutions, $\mathrm{INST}_{\mathrm{c}}$, for CCEF c.

This hypothesis is evaluated in terms of a linear regression of $\mathrm{NR}_{c}$ on $\mathrm{INST}_{c}$, and the results are presented in Table 5. (Since $\mathrm{NR}_{\mathrm{c}}$ appears as the dependent variable, this regression is immune to a generated regressor problem.) Three $\mathrm{NR}_{\mathrm{c}}$ 's 


\section{Table 5: OLS Estimates Of The Elasticity Of Noise With Respect To Institutional Ownership U.S. CCEF's}

Noise Ratio

(1)
Elasticity

(2)

A. Complete Sample

Normal

$\lambda=0$

Scaled- $t$

$\lambda=0$

Scaled-t

$\lambda \neq 0$

B. Trimmed Sample

Normal

$\lambda=0$

Scaled-t

$\lambda=0$

Scaled- $\mathrm{t}$

$\lambda \neq 0$
$-0.097$

(0.082)

$-0.162 * *$

(0.044)

$-0.144^{*}$

(0.087)

$-0.107$

(0.095)

$-0.141 * *$

(0.051)

$-0.161^{* *}$

(0.072) $\alpha$

(3)

及

(4)

Adj. $\mathbf{R}^{2}$

(5)

$-0.443$

(0.378)

0.838
$(0.069)$

0.967

(0.041)

$-0.808$

(0.222)

0.859

(0.072)

$-0.648$

(0.392)

(0.079)

(0.447)

0.960

(0.046)

$-0.729$

(0.262)

0.917

(0.062)

$-0.784$

(0.350)

0.005

0.126

0.007

0.193

0.033

0.079 
Notes to Table 5

Estimates based on $\mathrm{NR}_{\mathrm{c}}=\alpha+\beta^{*} \mathrm{INST}_{\mathrm{c}}+\mathrm{e}_{\mathrm{c}}$, where $\mathrm{c}$ indexes the CCEF's. The elasticity in column (2) equals $\beta * \operatorname{MEAN}\left[\operatorname{INST}_{\mathrm{c}}\right] / \mathrm{MEAN}\left[\mathrm{NR}_{\mathrm{c}}\right]$. ** and $*$ indicate statistical significance of the estimated elasticities at the 5\% and 10\% levels, respectively. The $\mathrm{NR}_{\mathrm{c}}$ 's in the first, second, and third rows of panels A and B are taken from column 2 of Tables 2, 3, and 4, respectively. $\mathrm{INST}_{\mathrm{c}}$ is the percentage of outstanding equity owned by institutions (a bank, insurance company, investment companies (mutual funds) and their managers, independent investment advisor (brokerage companies), or a college/university endowment). Only institutions that manage over $\$ 100$ million are required to file, and filers may omit small holdings under 10,000 shares or $\$ 200,000$. The data are drawn from the CDA/Spectrum database on WRDS. INST $_{c}$ equals the average institutional ownership stated as a percentage of outstanding shares. It is computed as the mean of $\operatorname{INST}_{\mathrm{c}, \mathrm{t}}$, where $\mathrm{INST}_{\mathrm{c}, \mathrm{t}}$ is institutional ownership for CCEF $\mathrm{c}$ at time $\mathrm{t}$ and is defined as the sum over all institutions (i) of shares held by institutions at the end of the year $\left(\mathrm{SHARES}_{\mathrm{i}, \mathrm{c}, \mathrm{t}}\right)$ divided by the number of shares outstanding in millions at the end of the year $\left(\mathrm{SHROUT}_{\mathrm{c}, \mathrm{t}} * 1,000,000\right)$. The results in panel A are based on a sample of 52 out of the 54 CCEF's listed in Table 1 ; $\mathrm{INST}_{\mathrm{c}}$ data are not available for the Emerging Germany Fund and the Portugal Fund. The results in Panel B are based on a sample of 48 CCEF's that has been trimmed to reduce the possible effect of outliers -- two CCEF's (Kleinwort Benson Australian Fund and Fidelity Korea Fund) with relatively low $\mathrm{NR}_{\mathrm{c}}$ 's (from Table 4) and two CCEF's (Jardine Fleming India Fund and Southern Africa Fund) with relatively high INST ${ }_{c}$ 's.

are used and are taken from column 2 of Tables 2, 3, and 4. INST $\mathrm{c}$ is taken from column 9 of Table 1 (see the Notes to Table 5 for the precise definition of institutional ownership and other details). As shown in panel A, noise is negatively associated with institutional ownership for each measure of noise. This relation is statistically different from zero at conventional levels of significance for the two $\mathrm{NR}_{\mathrm{c}}$ 's based on the Scaled-t distribution. The elasticity of noise with respect to institutional ownership is about -0.15 (column 2). This result is robust in two dimensions. First, the linear regression model is expanded to included quadratic and cubic terms. The elasticities (not reported) range between -0.10 and -0.20 , though they tend to be estimated less precisely than those in Table 5 . Second, panel B repeats this exercise but with a sample of CCEF's that are trimmed to reduce the potential effects of outliers, and results similar to those for the complete sample are obtained. The associations reported in Table 5 surely do not necessarily imply a causal role for institutional ownership, as a preference by 
institutions for less volatile funds, among other factors, provides a plausible alternative interpretation. ${ }^{13}$ This important caveat notwithstanding, the results in Table 5 provide some suggestive evidence of an interesting relation between noise and the "smart money."

\section{The United Kingdom And The Securities Transaction Tax}

Further insights about the importance of noise and its sensitivity to the trading environment can be obtained by repeating the above exercise on CCEF's traded in the United Kingdom. Meaningful comparisons can be drawn because these two equity markets are widely viewed as the most developed in the world. Moreover, only the United Kingdom imposes a securities transaction tax.

Estimated NR's are presented in summary fashion in Table 6 for 32 U.K. CCEF's. (Returns and exchange rate data are taken from Datastream; the percentage change in the FTSE 100 is used for the market return.) The NR's in columns (2) and (3) are based on the Normal and Scaled-t distributions, respectively, and on the assumption of no leakage of information during holidays. This latter assumption is relaxed in column (4). Two interesting results emerge. First, relative to the U.S. NR's, the average estimates for the United Kingdom are much lower: 0.410 vs. 0.767 for the Normal distribution without leakage, 0.644 vs. 0.838 for the Scaled-t distribution without leakage, and 0.363 vs. 0.759 for the Scaled-t distribution with leakage. Second, the numerous Japanese CCEF's provide further evidence that noise is unrelated to the characteristics of the non-

\footnotetext{
${ }^{13}$ There is a bit of indirect evidence against the alternative interpretation that institutional owners favor equities with lower volatility, as measured by stock returns. Gompers and Metrick (2001, Table IV) report that the relation between institutional ownership and volatility is negative and statistically significant (at the 5\% level) in only $13 \%$ of the cross-section regressions. Contrary to the alternative interpretation, $46 \%$ of their cross-section regressions yield a statistically significant positive relation between institutional ownership and volatility. While the volatility definitions used in this study differs from the noise measure that is the object of our empirical investigation, this evidence weighs against the plausibility of the alternative interpretation.
} 


\section{Table 6: Estimates Of Noise, Information, And The Noise Ratio Returns Distributed Normal, Scaled-t, Scaled-t With Information Affecting Holiday Returns $(\lambda \geq 0)$ U.K. CCEF's}

\section{Country Closed-End Fund (CCEF)}

(1)

Canadian General Investments Ltd
JPMF Chinese
German Smaller Companies
JPMF Indian
New India IT
Edinburgh Java
Gartmore Irish Growth Fund
Baillie Gifford Japan
Baillie Gifford Shin Nippon
Edinburgh Japan
Fidelity Japanese Value
Gartmore Select Japanese
GT Japan
Henderson Japan
Invesco Japan Discovery
Invesco Tokyo
JPMF Japanese
JPMF Japanese Smaller Companies
Martin Currie Japan
Perpetual Japan
Schroder Japanese Growth
Korea-Europe Fund
Schroder Korea
JF Philippine
JPMF Russian
Old Mutual S. Africa
Aberdeen New Thai
Edinburgh US Tracker
Foreign \& Colonial US Smaller
JPMF American
JPMF US Discovery
US Smaller Companies
Mean
Median

\author{
Normal \\ $\lambda=0$
}

(2)

0.202

0.393

0.532

0.497

0.555

0.670

0.400

0.283

0.357

0.301

0.305

0.260

0.386

0.386

0.387

0.371

0.102

0.338

0.337

0.331

0.353

0.614

0.609

0.150

0.786

0.403

0.391

0.521

0.785

0.116

0.620

0.386

0.410

0.386
Scaled-t
$\lambda=0$

(3)

0.027

0.852

1.000

0.673

1.000

0.938

0.953

0.411

0.585

0.494

0.448

0.437

0.695

0.721

0.634

0.559

0.730

0.679

0.430

0.476

0.529

0.382

0.732

1.000

0.431

0.973

0.799

0.455

0.732

0.506

0.543

0.791

0.644

0.654
Scaled-t

$\lambda \neq 0$

(4)

0.018

0.852

0.048

0.312

1.000

0.056

0.858

0.109

0.194

0.494

0.144

0.161

0.695

0.721

0.337

0.278

0.640

0.168

0.277

0.145

0.491

0.054

0.100

1.000

0.060

0.973

0.189

0.010

0.385

0.011

0.029

0.791

0.363

0.236 
Notes to Table 6

See Notes to Table 1 for details about the data. The table entries in columns (2), (3), and (4) are comparable to those in column (2) of Tables 2, 3, and 4, respectively, except that the entries in Table 6 are computed for U.K. CCEF's. In column (2), returns are assumed to be distributed normal, and there is no leakage of information during holidays. In column (3), returns are assumed to be distributed Scaled-t, and there is no leakage of information during holidays. In column (4), returns are assumed to be distributed Scaled-t, and there is the possibility of leakage of information during holidays. All parameters are estimated by maximum likelihood based on a grid search. See the notes to Tables 2, 3, and 4 for details.

U.K. market in which the underlying assets for the CCEF are located. For the 14 Japanese funds traded in the U.K., the NR's in column 4 range widely -- the standard deviation is 0.225 (relative to a mean of 0.336 ) and the high and low values are 0.721 and 0.109 .

Given the depth and sophistication of the U.S. and U.K. equity markets, the first result seems paradoxical. However, an important difference between the equity markets is that the United Kingdom has assessed a Stamp Duty Reserve Tax since 1891 and the tax base was broadened and the tax rate reduced in 1986 (Summers and Summers, 1989, Section 2.2). This tax is assessed at the rate of $0.5 \%$ based on the value of paperless transactions. ${ }^{14}$ If this transactions tax is effective in reducing noise trading, we would expect that, for those countries in which both U.K. and U.S. CCEF's invest, the NR's for the United Kingdom will be less than those for the United States. There are 11 countries for which CCEF's exist in both the United Kingdom and the United States. The NR's for these matched CCEF's are presented in Table 7, as well as the ratio of the U.K. to the U.S. noise ratios (RNR). About one-half of the RNR's are below 0.700. The results in Table 7 do not merely reflect lower volatility for U.K. equities, as the

\footnotetext{
${ }^{14}$ There is a closely related Stamp Duty for transactions using paper forms, though these are relatively rare.
} 
U.K. equity market is $19 \%$ more volatile than the U.S. market. ${ }^{15}$ For the most general model based on a Scaled-t distribution and the possibility of information leakage during holidays, the RNR's listed between columns (6) and (7) have a mean value of 0.634. Table 7 offers some support for Summers and Summers' "cautious case" for a securities transactions tax to curb volatility due to noise and verifies a claim made long ago by Keynes (1936, pp. 159-160; bracketed word added by the authors),

That the sins [speculation] of the London Stock Exchange are less than those of Wall Street may be due, not so much to differences in national character, as to the fact that to the average Englishman Throgmorton Street is, compared with Wall Street to the average American, inaccessible and very expensive. The jobber's "turn", the high brokerage charges and the heavy transfer tax payable to the Exchequer, which attend dealings on the London Stock Exchange, sufficiently diminish the liquidity of the market (although the practice of fortnightly accounts operates the other way) to rule out a large proportion of the transactions characteristic of Wall Street. The introduction of a substantial Government transfer tax on all transactions might prove the most serviceable reform available, with a view to mitigating the predominance of speculation over enterprise in the United States.

The evidence presented in this section should only be viewed as preliminary, as other frictions that may also reduce noise -- such as trading costs and capital income taxes -- need to be controlled for in a fuller empirical assessment of the securities transaction tax.

\footnotetext{
${ }^{15}$ The aggregate volatilities are computed as the coefficients of variation in the percentage change in the price indices of the S\&P500 and FTSE100. These statistics are merely suggestive, as there can be a great deal of distance between the volatility for the overall market and the volatility due to noise.
} 


\section{Table 7: Noise Ratio Means And The Ratio Of The Noise Ratios U.S. And U.K. CCEF's For The Same Country}

\begin{tabular}{|c|c|c|c|c|c|c|}
\hline \multirow{2}{*}{$\begin{array}{c}\text { Country } \\
\text { (1) }\end{array}$} & \multicolumn{2}{|c|}{ Normal, $\lambda=0$} & \multicolumn{2}{|c|}{ Scaled-t, $\lambda=0$} & \multicolumn{2}{|c|}{ Scaled-t, $\lambda \neq 0$} \\
\hline & $\begin{array}{l}\text { U.S. } \\
\text { (2) }\end{array}$ & $\begin{array}{l}\text { U.K. } \\
\text { (3) }\end{array}$ & $\begin{array}{l}\text { U.S. } \\
\text { (4) }\end{array}$ & $\begin{array}{l}\text { U.K. } \\
\text { (5) }\end{array}$ & $\begin{array}{l}\text { U.S. } \\
(6)\end{array}$ & $\begin{array}{c}\text { U.K. } \\
\text { (7) }\end{array}$ \\
\hline China & \multicolumn{2}{|c|}{ RNR $=0.480$} & \multicolumn{2}{|c|}{ RNR $=0.964$} & \multicolumn{2}{|c|}{ RNR $=1.007$} \\
\hline Germany & \multicolumn{2}{|c|}{ RNR $=0.586$} & \multicolumn{2}{|c|}{$\mathrm{RNR}=1.064$} & \multicolumn{2}{|c|}{$\mathrm{RNR}=0.055$} \\
\hline India & \multicolumn{2}{|c|}{$\mathrm{RNR}=0.812$} & \multicolumn{2}{|c|}{$\mathrm{RNR}=1.184$} & \multicolumn{2}{|c|}{ RNR $=1.015$} \\
\hline Indonesia & \multicolumn{2}{|c|}{$\mathrm{RNR}=0.824$} & \multicolumn{2}{|c|}{$\mathrm{RNR}=0.971$} & \multicolumn{2}{|c|}{$\mathrm{RNR}=0.058$} \\
\hline Ireland & \multicolumn{2}{|c|}{$\mathrm{RNR}=0.400$} & \multicolumn{2}{|c|}{$\mathrm{RNR}=0.953$} & \multicolumn{2}{|c|}{$\mathrm{RNR}=0.858$} \\
\hline Japan & \multicolumn{2}{|c|}{$\mathrm{RNR}=0.369$} & \multicolumn{2}{|c|}{$\mathrm{RNR}=0.603$} & \multicolumn{2}{|c|}{$\mathrm{RNR}=0.374$} \\
\hline Korea & \multicolumn{2}{|c|}{$\mathrm{RNR}=0.749$} & \multicolumn{2}{|c|}{$\mathrm{RNR}=0.672$} & \multicolumn{2}{|c|}{$\mathrm{RNR}=0.798$} \\
\hline Philippines & \multicolumn{2}{|c|}{ RNR $=0.150$} & \multicolumn{2}{|c|}{ RNR $=1.019$} & \multicolumn{2}{|c|}{ RNR $=1.045$} \\
\hline Russia & \multicolumn{2}{|c|}{$\mathrm{RNR}=0.838$} & \multicolumn{2}{|c|}{$R N R=0.579$} & \multicolumn{2}{|c|}{$R N R=0.137$} \\
\hline South Africa & $\begin{array}{r}0.797 \\
\mathrm{R}\end{array}$ & $\begin{array}{l}0.403 \\
06\end{array}$ & $\begin{array}{r}0.763 \\
\mathrm{R}\end{array}$ & $\begin{array}{l}0.973 \\
275\end{array}$ & $\begin{array}{r}0.686 \\
\mathrm{R}\end{array}$ & $\begin{array}{l}0.973 \\
118\end{array}$ \\
\hline Thailand & $\begin{array}{r}0.893 \\
\mathrm{R}\end{array}$ & $\begin{array}{l}0.391 \\
138\end{array}$ & $\begin{array}{r}0.915 \\
\mathrm{RN}\end{array}$ & $\begin{array}{l}0.799 \\
873\end{array}$ & $\begin{array}{r}0.904 \\
\mathrm{R}\end{array}$ & $\begin{array}{l}0.189 \\
209\end{array}$ \\
\hline
\end{tabular}

Notes to Table 7

The table entries (apart from the RNR's) are means of noise ratios (NR) for CCEF's by the country in which the assets are invested. The figures in columns (2), (4), and (6) are taken from column (2) of Tables 2, 3, and 4, respectively; the figures in columns (3), (5), and (7) from columns (2), (3), and (4), respectively, of Table 6. RNR equals the ratio of the U.K. entry to the U.S. entry for a given country. 


\section{Discussion}

Several papers that have assessed noise and its role in equity markets or that have studied CCEF's are reviewed in this section (though the discussion is not exhaustive). Our approach is related to the well-known study of French and Roll (1986) that exploits a very interesting natural experiment. ${ }^{16}$ They compare equity volatilities between trading and non-trading days and find that the hourly return variance during trading days is 71.8 times greater than over weekends (Friday close to Monday close; p. 223). As the authors note, this huge number can be traced to the absence of noise traders or a reduced flow of fundamental information on non-trading days. They use the closure of the New York Stock Exchange on Wednesdays during the second half of 1968 to differentiate between the noise and information explanations. The two-day return volatility from Tuesdays to Thursdays during the Wednesday exchange holidays is 1.15 times greater than the one-day volatility (the latter computed from January 1963 to December 1982). If return volatilities were unaffected by the trading process, this ratio should be 2.00 . Clearly, trading raises volatility. While extremely informative, this particular natural experiment is unable to differentiate between two competing and very different hypotheses -- whether the trading process reveals information (which French and Roll favor based on autocorrelation tests) or generates noise. ${ }^{17} \mathrm{By}$

\footnotetext{
${ }^{16}$ Our approach is also related to Kamstra, Kramer, and Levi (2000, 2003) and Hirshleifer and Shumway (2003), who use the natural experiments of the exogenous shifts to and from daylight saving time and in the amount of daylight and sunshine to identify behavior in equity markets that deviates from the efficient markets benchmark.

${ }^{17}$ French and Roll discriminate between the private information and noise hypotheses by examining weekly return volatility for weeks with and without an exchange holiday. Consistent with the noise hypothesis, weekly return volatility is lower during weeks with exchange holidays, but this difference is not statistically significant. Using the natural experiment of occasional Saturday trading on the Tokyo Stock Exchange, Barclay, Litzenberger, and Warner (1990) find that, for weeks with Saturday trading, the weekly return volatility is unchanged relative to weeks without Saturday trading; this result is consistent with the private information hypothesis. By contrast, the weekly volume for weeks with Saturday trading is higher, which
} 
contrast, our focus on non-U.S. holidays generates a direct estimate of the impact of noise. Information may not be completely turned-off during non-U.S. holidays, and the double mixture model allows for this information leakage.

In an interesting paper, Pontiff (1997) documents that the volatility of closed-end fund prices is excessive, being $64 \%$ greater than the volatility of fundamentals as represented by NAV's. While there is much useful information in these results, several issues arise linking these volatilities to noise. First, Abraham, Elan, and Marcus (1993) show that the premium in closed-end equity and bond funds have very similar correlations with the market. This coincidence of results may reflect time varying risk premium affecting both equity and bond markets, and it raises questions about interpreting variations in the premium on closed-end equity funds as reflecting noise. Second, if noise affects equity prices in U.S. markets, then presumably noise affects the non-U.S. market as well. Thus, NAV is a noisy measure of fundamental value. Third, interactions between fundamentals and noise compromise the use of premia to measure noise. Consider the following accounting identity relating the price of the $\operatorname{CCEF}(\mathrm{P})$ to fundamental value $(\mathrm{F}$, measured by the NAV) and the premium, $\Phi[\mathrm{N}, \mathrm{F}]$, where the latter depends on both noise $(\mathrm{N})$ and fundamentals,

$$
\mathrm{P}=\Phi[\mathrm{N}, \mathrm{F}] \mathrm{F}
$$

Taking $\operatorname{logs}$, totally differentiating with respect to $\mathrm{P}, \mathrm{N}$, and $\mathrm{F}$, defining returns $\left(\mathrm{R}_{\mathrm{X}}\right)$ as the percentage change in $\mathrm{P}, \mathrm{F}$, and the premium with respect to $\mathrm{N}$ and $\mathrm{F}$, computing variances, and then rearranging terms, we obtain the following expression,

can be interpreted as consistent with the noise hypothesis (per French and Roll) or the private information hypothesis (as argued by Barclay, Litzenberger, and Warner). 


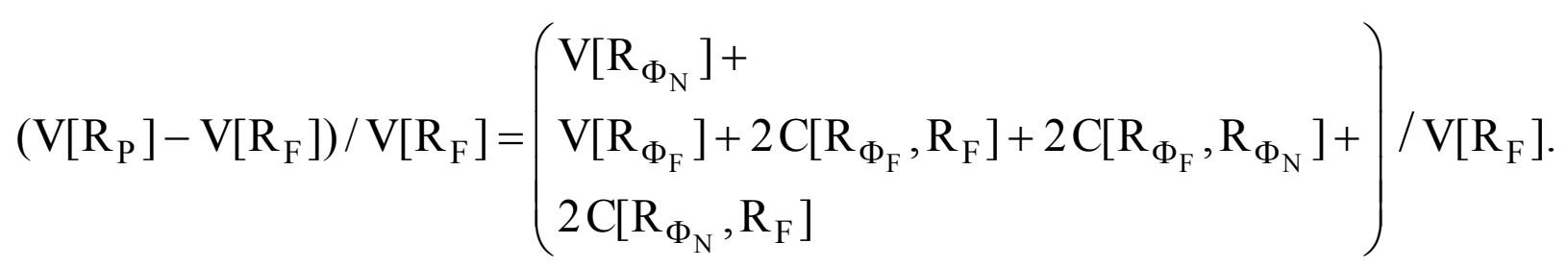

where $C[$.$] is the covariance operator and \Phi_{\mathrm{N}}$ and $\Phi_{\mathrm{F}}$ refer to partial derivatives of the premium with respect to $\mathrm{N}$ and $\mathrm{F}$, respectively. The left-side of equation (9) equals the $64 \%$ figure reported by Pontiff. Equation (9) is a useful measure of the variance due to noise, defined by $\mathrm{V}\left[\mathrm{R}_{\Phi_{\mathrm{N}}}\right]$, provided the remaining four terms in the numerator are zero. The results of Campbell and Kyle (1993) and Klibanoff, Lamont, and Wizman (1998) suggest that fundamentals affect the premium, and hence $\mathrm{R}_{\Phi_{\mathrm{F}}}$ is time-varying. Even if $\mathrm{R}_{\Phi_{\mathrm{F}}}$ is constant and hence the three terms in the second line of equation (9) equal zero, the $\mathrm{C}\left[\mathrm{R}_{\Phi_{\mathrm{N}}}, \mathrm{R}_{\mathrm{F}}\right]$ term disrupts accurately measuring noise by the variances in market prices and NAV's. The approach presented in the present study avoids these issues in estimating the extent of noise.

Several studies have documented excess volatility in equities relative to various measures of fundamentals. Roll $(1984,1988)$ finds that the volatilities of orange juice futures and monthly equity returns, respectively, are poorly explained by ex-post fundamentals. In the case of equity returns, about $20 \%$ of the variation in daily returns and about $35 \%$ of the variation in monthly returns are explained by fundamentals. Cutler, Poterba, and Summers (1989, Table 1) report that contemporaneous macro variables capturing important news items explain about $20 \%$ of the variation in monthly aggregate returns (for the period 1926-1985) and about $6 \%$ of the variation in annual aggregate returns (1871-1986). Equity prices are much more volatile than the present value of the dividend stream computed 
with a constant discount rate (LeRoy and Porter (1981), Shiller (1981), and West (1988)), and equity returns are much more volatile than consumption growth (Campbell, 1999). These excess volatility studies suggest a natural and quantitatively important role for noise in filling the wide gap between equity prices (or returns) and fundamentals.

\section{Conclusions}

This paper uses the natural experiment provided by foreign holidays to quantify the impact of noise on equity returns in highly developed equity markets. Our baseline results highlight that there is a great deal of noise in the returns of CCEF's in the United States. These results prove robust to kurtosis and the possibility of information leakage during holidays. Noise is negatively related to institutional ownership of U.S. CCEF's and is much less important for U.K. CCEF's. The lower levels of noise for matched U.K. and U.S. CCEF's suggests that the securities tax imposed in the United Kingdom may be effective in reducing equity market noise.

Noise disrupts financial markets, raises the cost of capital, impedes arbitrageurs, complicates stabilization policies, and is central to the issue of stock market efficiency. Merton (1987, p. 93) states the critical test: 
"The theory [the rational market hypothesis] is not, however, a tautology. It is not consistent with models or empirical facts that imply that either stock prices depend in an important way on factors other than the fundamentals underlying future cash flows and discount rates, ...

A quantitatively important role for noise documented in this study thus challenges the efficient market model and points toward the behavioral finance alternative as a framework model for understanding equity markets.

\section{References}

Abraham, Abraham, Elan, Don, and Marcus, Alan J., "Does Sentiment Explain Closed-End Fund Discounts?: Evidence from Bond Funds," Financial Review 28 (November 1993), 607-616.

Aparicio, Felipe M., and Estrada, Javier, "Empirical Distributions of Stock Returns: European Securities Markets 1990-95," The European Journal of Finance 7 (2001), 1-21.

Arnott, Robert D., Hsu, Jason, and Moore, Philip, "Fundamental Indexation," Financial Analysts Journal 61 (March/April 2005), 83-99.

Baker, Malcolm, Stein, Jeremy C., and Wurgler, Jeffrey, "When Does The Market Matter? Stock Prices and the Investment of Equity-Dependent Firms," Quarterly Journal of Economics 118 (August 2003), 969-1005.

Ball, Turan G., Cakici, Nusret, Yan, Xuemin (Sterling), and Zhang, Zhe, “Does Idiosyncratic Risk Really Matter?," Journal of Finance 60 (April 2005), 905-930.

Barclay, Michael J., Litzenberger, Robert H., and Warner, Jerold B., "Private Information, Trading Volume, And Stock Return Variances," Review Of Financial Studies 3 (1990), 233-254. 
Black, Fischer, "Noise," Journal of Finance 41 (July 1986), 529-543. Reprinted as Chapter 1 in Richard H. Thaler (ed.), Advances In Behavioral Finance (New York: Russell Sage Foundation, 1993), 3-22.

Bodurtha, James N., Jr., Kim, Dong-Soon, Lee, Charles M.C., "Closed-end Country Funds and U.S. Market Sentiment," The Review of Financial Studies 8 (Fall 1995), 879-918.

Brown, David P., and Ferreira, Miguel A., "Information in the Idiosyncratic Volatility of Small Firms," University of Wisconsin (January 2005).

Campbell, John Y., "Asset Prices, Consumption, and the Business Cycle," in John B. Taylor and Michael Woodford (eds.), Handbook Of Macroeconomics, Volume 1C (Amsterdam: Elsevier North-Holland), 1999), 1231-1303.

Campbell, John Y., and Kyle, Albert S., "Smart Money, Noise Trading and Stock Price Behaviour," Review of Economic Studies 60 (January 1993), 1-34

Campbell, John Y., Lo, Andrew W., and MacKinlay, A. Craig, The Econometrics of Financial Markets (Princeton: Princeton University Press, 1997).

Chen, Nai-Fu, Kan, Raymond, and Miller, Merton H., "Are the Discounts on Closed-End Funds a Sentiment Index?" and "Rejoinder," Journal of Finance 48 (June 1993), 795-800 and 809-810.

Chirinko, Robert S., and Schaller, Huntley, "Business Fixed Investment and 'Bubbles': The Japanese Case," American Economic Review 91 (June 2001), 663-680.

Chirinko, Robert S., and Schaller, Huntley, "Glamour vs. Value: The Real Story," Emory University (September 2006).

Chopra, Navin, Lee, Charles M.C. Shleifer, Andrei, and Thaler, Richard H., "Yes, Discounts on Closed-End Funds Are a Sentiment Index" and "Summing Up," Journal of Finance 48 (June 1993), 801-808 and 811-812.

Cutler, David M., Poterba, James M., and Summers, Lawrence H., "What Moves Stock Prices?," The Journal of Portfolio Management (Spring 1989), 4-12. Reprinted as Chapter 5 in Richard H. Thaler (ed.), Advances In Behavioral Finance (New York: Russell Sage Foundation, 1993), 133-151. 
De Long, J. Bradford, Shleifer, Andrei, Summers, Lawrence H., and Waldmann, Robert J., "Noise Trader Risk in Financial Markets," Journal of Political Economy 98 (August 1990), 703-738. Reprinted as Chapter 2 in Richard H. Thaler (ed.), Advances In Behavioral Finance (New York: Russell Sage Foundation, 1993), 23-58.

Easley, David, Hvidkjaer, Soeren, and O’Hara, Maureen, "Is Information Risk a Determinant of Asset Returns?," Journal of Finance 57 (October 2002), 2185-2221.

Fama, Eugene, "Efficient Capital Markets: A Review of Theory and Empirical Work,” Journal of Finance 25 (1970), 383-417.

Fama, Eugene, "Efficient Capital Markets II," Journal of Finance 46 (1991), 1575-1617.

Fischer, Stanley, and Merton, Robert C., "Macroeconomics and Finance: The Role of the Stock Market," in Karl Brunner and Allan H. Meltzer (eds.), Essays on Macroeconomic Implications of Financial and Labor Markets and Political Processes, Carnegie-Rochester Conference Series on Public Policy 21 (Autumn 1984), 57-108.

French, Kenneth R. and Roll, Richard, "Stock Return Variances: The Arrival of Information and the Reaction of Traders," Journal of Financial Economics 17 (1986), 5-26. Reprinted as Chapter 8 in Richard H. Thaler (ed.), Advances In Behavioral Finance (New York: Russell Sage Foundation, 1993), 219-245.

Gilchrist, Simon, Himmelberg, Charles, Huberman, Gur, "Do Stock Price Bubbles Influence Corporate Investment?" Journal of Monetary Economics 52 (May 2005), 805-827.

Gompers, Paul A., and Metrick, Andrew, "Institutional Investors and Equity Prices," Quarterly Journal of Economics 116 (February 2001), 229-260.

Goyal, Amit, and Santa-Clara, Pedro, "Idiosyncratic Risk Matters!," Journal of Finance 58 (June 2003), 975-1008.

Hamilton, James D., Time Series Analysis (Princeton: Princeton University Press, 1994). 
Hardouvelis, G. La Porta, R., Wizman, T.A., "What Moves the Discount on Country Equity Funds?," in Jeffrey Frankel (ed.) The Internationalization of Equity Markets (Chicago: University of Chicago Press (for the NBER), 1994), 345-397.

Hirshleifer, David, and Shumway, Tyler, "Good Day Sunshine: Stock Returns and the Weather," Journal of Finance 58 (June 2003), 1009-1032.

Kamstra, Mark J., Kramer, Lisa A., and Levi, Maurice D., "Losing Sleep At The Market: The Daylight Saving Anomaly," American Economic Review 90 (September 2000), 1005-1011.

Kamstra, Mark J., Kramer, Lisa A., and Levi, Maurice D., "Winter Blues: A SAD Stock Market Cycle," American Economic Review 93 (March 2003), 324-343.

Keynes, John Maynard, The General Theory of Employment, Interest, and Money (New York: Harcourt Brace, 1936). Reprinted in 1964, First Harbinger Edition.

Klibanoff, Peter, Lamont, Owen A., and Wizman, Thierry A., "Investor Reaction to Salient News in Closed-End Country Funds," Journal of Finance 53 (April 1998), 673-699.

Lee, Charles M.C., Shleifer, Andrei, and Thaler, Richard H., "Investor Sentiment and the Closed-End Fund Puzzle," Journal of Finance 46 (March 1991), 75-109. Reprinted as Chapter 3 in Richard H. Thaler (ed.), Advances In Behavioral Finance (New York: Russell Sage Foundation, 1993), 59-106.

Lei, Vivian, Noussair, Charles N., and Plott, Charles R., "Nonspeculative Bubbles in Experimental Asset Markets: Lack of Common Knowledge vs. Actual Irrationality," Econometrica 69 (July 2001), 831-859.

LeRoy, Stephen F., "Efficient Capital Markets and Martingales," Journal of Economic Literature 27 (December 1989), 1583-1621.

LeRoy, Stephen F., and Porter, Richard D., "The Present-Value Relation: Tests Based on Implied Variance Bounds," Econometrica 49 (May 1981), 555-574. 
Levy, Haim, "Equilibrium in an Imperfect Market: A Constraint on the Number of Securities in the Portfolio," American Economic Review 68 (September 1978), 643-658.

Malkiel, Burton G., "The Efficient Markets Hypothesis and Its Critics," Journal of Economic Perspectives 17 (Winter 2003), 59-82.

Malkiel, Burton G., and Xu, Yexiao, "Idiosyncratic Risk and Security Returns," University of Texas at Dallas (November 2002).

McLachlan, Geoffrey J., and Peel, David, Finite Mixture Models (New York: John Wiley \& Sons, 2000).

Merton, Robert C., "On the Current State of the Stock Market Rationality Hypothesis," in Rudiger Dornbusch, Stanley Fischer, and John Bossons (eds.), Macroeconomics and Finance: Essays in Honor of Franco Modigliani (Cambridge: MIT Press, 1987), 93-124.

Polk, Christopher, and Sapienza, Paola, "The Real Effects of Investor Sentiment," Northwestern (December 2003).

Pontiff, Jeffrey, "Excess Volatility and Closed-End Funds," American Economic Review 87 (March 1997), 155-169.

Praetz, Peter D., "The Distribution of Share Price Changes," Journal of Business 45 (1972), 49-55.

Press, S. James, “A Compound Events Model for Security Prices," Journal of Business 40 (July 1967), 317-335.

Roll, Richard, "Orange Juice and Weather," American Economic Review 74 (December 1984), 861-880.

Roll, Richard, "R²," Journal of Finance 43 (July 1988), 541-566.

Shiller, Robert J., "Do Stock Prices Move Too Much To Be Explained by Subsequent Changes in Dividends?," American Economic Review 71 (June 1981), 421-436.

Shiller, Robert J., Market Volatility (Cambridge: MIT Press, 1990). 
Shiller, Robert J., "From Efficient Markets Theory to Behavioral Finance," Journal of Economic Perspectives 17 (Winter 2003), 83-104.

Shleifer, Andrei, Inefficient Markets: An Introduction to Behavioral Finance (Oxford: Oxford University Press, 2000).

Shleifer, Andrei, and Summers, Lawrence H., "The Noise Trader Approach to Finance," Journal of Economic Perspectives 4 (Spring 1990), 19-33.

Siegel, Jeremy J., "The 'Noisy Markets' Hypothesis," The Wall Street Journal (June 14, 2006), A14.

Summers, Lawrence H., and Summers, Victoria, P., "When Financial Markets Work Too Well: A Cautious Case for a Securities Transactions Tax," Journal of Financial Services Research 3 (1989), 261-286.

Thaler, Richard H. (ed.), Advances In Behavioral Finance (New York: Russell Sage Foundation, 1993).

Thaler, Richard H. (ed.), Advances In Behavioral Finance, Volume II (Princeton: Princeton University Press, 2005).

Weaver, Robert S., International holidays: 204 countries from 1994 through 2015 (Jefferson, North Carolina: McFarland Press, 1995).

West, Kenneth D., "Dividend Innovations and Stock Price Volatility," Econometrica 56 (January 1988), 37-62. 


\section{Appendix: The Double Mixture Model Of Returns:}

\section{Derivation Of The Likelihood Function And Likelihood Ratio Test}

This appendix derives the likelihood function and likelihood ratio test statistic for the double mixture model of returns. This is the most general of the three models estimated in this paper, and the other two models are derived as special cases under suitable parametric restrictions. We begin with the model of returns.

\section{Returns}

Returns are defined as a mixture of holiday and standard day returns,

$$
\mathrm{R}_{\mathrm{t}}=\rho_{\mathrm{t}} \mathrm{R}_{\mathrm{H}, \mathrm{t}}+\left(1-\rho_{\mathrm{t}}\right) \mathrm{R}_{\mathrm{S}, \mathrm{t}} \quad \forall \mathrm{t},
$$

where $R_{t}, R_{H, t}$, and $R_{S, t}$ are returns for the full sample, holidays, and standard days (non-holidays), respectively, and $\rho_{\mathrm{t}}$ is the mixing variable equal to one for holidays and zero for standard days.

Holiday returns are defined as a mixture of noise $\left(\mathrm{R}_{\mathrm{t}}^{\mathrm{N}}\right)$ and information $\left(\mathrm{R}_{\mathrm{t}}^{\mathrm{I}}\right)$ returns,

$$
\begin{aligned}
\mathrm{R}_{\mathrm{H}, \mathrm{t}}= & \mathrm{R}_{\mathrm{t}}^{\mathrm{N}}+\delta_{\mathrm{t}} \mathrm{R}_{\mathrm{t}}^{\mathrm{I}} \quad \forall \mathrm{t} \in \mathfrak{I}^{\mathrm{H}} \text { where } \mathfrak{I}^{\mathrm{H}}=\{\mathrm{t}: \mathrm{t}=\text { holiday }\} \\
& \mathrm{R}_{\mathrm{t}}^{\mathrm{N}} \sim \text { Scaled }-\mathrm{t}\left(0, \mathrm{~V}^{\mathrm{N}}, \mathrm{k}\right) \\
& \mathrm{R}_{\mathrm{t}}^{\mathrm{I}} \sim \operatorname{Scaled}-\mathrm{t}\left(0, \mathrm{~V}^{\mathrm{I}}, \mathrm{k}\right) \\
& \delta_{\mathrm{t}} \sim \operatorname{Be}(\lambda)
\end{aligned}
$$


where $\delta_{\mathrm{t}}$ equals 1 if information arrives at date $\mathrm{t}$ and 0 otherwise. This mixing variable is distributed Bernoulli with mean $\lambda$. The returns due to noise and information are distributed Scaled-t with zero location parameter, a dispersion parameter equal to $\mathrm{V}^{\mathrm{N}}$ or $\mathrm{V}^{\mathrm{I}}$, and $\mathrm{k}$ degrees of freedom. Assuming independence between noise returns, information returns, and the arrival of information, we can express the holiday return variance $\left(\mathrm{V}_{\mathrm{H}}\right)$ as follows,

$$
\mathrm{V}_{\mathrm{H}}=\mathrm{V}^{\mathrm{N}}+\lambda \mathrm{V}^{\mathrm{I}}
$$

Returns on standard days are defined as the sum of both noise and information,

$$
\mathrm{R}_{\mathrm{S}, \mathrm{t}}=\mathrm{R}_{\mathrm{t}}^{\mathrm{N}}+\mathrm{R}_{\mathrm{t}}^{\mathrm{I}} \quad \forall \mathrm{t} \in \mathfrak{I}^{\mathrm{S}} \text { where } \mathfrak{I}^{\mathrm{S}}=\{\mathrm{t}: \mathrm{t}=\text { standard }\}
$$

The standard day variance $\left(\mathrm{V}_{\mathrm{S}}\right)$ can be expressed as follows,

$$
\mathrm{V}_{\mathrm{S}}=\mathrm{V}^{\mathrm{N}}+\mathrm{V}^{\mathrm{I}}
$$

\section{Densities And The Log Likelihood}

In our double mixture model, CCEF returns are characterized by a parameter vector, $\Psi$, containing four unknowns,

$$
\Psi=\left\{\mathrm{V}^{\mathrm{N}}, \mathrm{V}^{\mathrm{I}}, \mathrm{k}, \lambda\right\}
$$

Based on equation (A1), the density of CCEF returns $\left(\mathrm{f}\left(\mathrm{R}_{\mathrm{t}} ; \Psi\right)\right)$ is a mixture of the densities of holiday and standard day returns, 


$$
\mathrm{f}\left(\mathrm{R}_{\mathrm{t}} ; \Psi\right)=\rho_{\mathrm{t}} \mathrm{f}\left(\mathrm{R}_{\mathrm{H}, \mathrm{t}} ; \Psi\right)+\left(1-\rho_{\mathrm{t}}\right) \mathrm{f}\left(\mathrm{R}_{\mathrm{S}, \mathrm{t}} ; \Psi\right) \quad \forall \mathrm{t}
$$

Holiday returns are also defined as a mixture of returns. With the definition of returns given in equation (A2), the joint density for returns and information leakage is given by the sum of the conditional densities,

$$
\mathrm{f}\left(\mathrm{R}_{\mathrm{H}, \mathrm{t}} ; \Psi\right)=\mathrm{f}\left(\mathrm{R}_{\mathrm{t}} \mid \delta_{\mathrm{t}}=0\right) \mathrm{h}\left(\delta_{\mathrm{t}}=0\right)+\mathrm{f}\left(\mathrm{R}_{\mathrm{t}} \mid \delta_{\mathrm{t}}=1\right) \mathrm{h}\left(\delta_{\mathrm{t}}=1\right) \quad \forall \mathrm{t} \in \mathfrak{I}^{\mathrm{H}}
$$

where $h\left(\delta_{t}\right)$ is the unconditional density for $\delta_{t}$. Given the distribution assumptions in equations (A2), equation (A7) becomes,

$$
\mathrm{f}\left(\mathrm{R}_{\mathrm{H}, \mathrm{t}} ; \Psi\right)=\lambda \mathrm{f}\left(\mathrm{R}_{\mathrm{t}} ; \mathrm{V}^{\mathrm{N}}, \mathrm{V}^{\mathrm{I}}, \mathrm{k}\right)+(1-\lambda) \mathrm{f}\left(\mathrm{R}_{\mathrm{t}} ; \mathrm{V}^{\mathrm{N}}, \mathrm{k}\right) \quad \forall \mathrm{t} \in \mathfrak{J}^{\mathrm{H}}
$$

On standard days, returns are influenced by both noise and information,

$$
\mathrm{f}\left(\mathrm{R}_{\mathrm{S}, \mathrm{t}} ; \Psi\right)=\mathrm{f}\left(\mathrm{R}_{\mathrm{t}} ; \mathrm{V}^{\mathrm{N}}, \mathrm{V}^{\mathrm{I}}, \mathrm{k}\right) \quad \forall \mathrm{t} \in \mathfrak{I}^{\mathrm{S}}
$$

Combining equations (A7), (A9), and (A10), we have the following double mixture density,

$$
\begin{aligned}
\mathrm{f}\left(\mathrm{R}_{\mathrm{t}} ; \Psi\right) & =\rho_{\mathrm{t}}\left[\lambda \mathrm{f}\left(\mathrm{R}_{\mathrm{t}} ; \mathrm{V}^{\mathrm{N}}, \mathrm{V}^{\mathrm{I}}, \mathrm{k}\right)+(1-\lambda) \mathrm{f}\left(\mathrm{R}_{\mathrm{t}} ; \mathrm{V}^{\mathrm{N}}, \mathrm{k}\right)\right] \quad \forall \mathrm{t} . \\
& +\left(1-\rho_{\mathrm{t}}\right) \mathrm{f}\left(\mathrm{R}_{\mathrm{t}} ; \mathrm{V}^{\mathrm{N}}, \mathrm{V}^{\mathrm{I}}, \mathrm{k}\right)
\end{aligned}
$$

We assume that returns are distributed Scaled-t defined by the following density function, 


$$
\begin{gathered}
\mathrm{f}\left(\mathrm{R}_{\mathrm{t}} ; \mathrm{V}^{\mathrm{N}}, \mathrm{V}^{\mathrm{I}}, \mathrm{k}\right)=\frac{\Gamma\left(\frac{\mathrm{k}+1}{2}\right)}{\Gamma\left(\frac{\mathrm{k}}{2}\right) \sqrt{\pi(\mathrm{k}-2)\left(\mathrm{V}^{\#}\right)}}\left[1+\frac{\mathrm{R}_{\mathrm{t}}^{2}}{(\mathrm{k}-2)\left(\mathrm{V}^{\#}\right)}\right]^{-(\mathrm{k}+1) / 2} \quad \forall \mathrm{t}, \\
\mathrm{V}^{\#}=\left\{\mathrm{V}^{\mathrm{N}}, \mathrm{V}^{\mathrm{N}}+\mathrm{V}^{\mathrm{I}}\right\},
\end{gathered}
$$

where $\mathrm{k}$ is the degrees of freedom parameter and $\Gamma($.$) is the gamma function.$

The four unknown parameters in $\Psi$ are estimated using maximum likelihood. The log likelihood function is written as follows,

$$
\ln L(\Psi)=\sum_{\mathrm{t}=1}^{\mathrm{T}} \ln \mathrm{f}\left(\mathrm{R}_{\mathrm{t}} ; \Psi\right)
$$

where $\mathrm{f}\left(\mathrm{R}_{t} ; \Psi\right)$ is defined in equation (A11). Since the holiday mixing variable is non-stochastic, we can separate the log likelihood function into two components,

$$
\begin{aligned}
\ln L(\Psi) & =\sum_{\mathrm{t}=1}^{\mathrm{T}} \rho_{\mathrm{t}} \ln \left[\lambda \mathrm{f}\left(\mathrm{R}_{\mathrm{t}} ; \mathrm{V}^{\mathrm{N}}, \mathrm{V}^{\mathrm{I}}, \mathrm{k}\right)+(1-\lambda) \mathrm{f}\left(\mathrm{R}_{\mathrm{t}} ; \mathrm{V}^{\mathrm{N}}, \mathrm{k}\right)\right] \\
& +\sum_{\mathrm{t}=1}^{\mathrm{T}}\left(1-\rho_{\mathrm{t}}\right) \ln \mathrm{f}\left(\mathrm{R}_{\mathrm{t}} ; \mathrm{V}^{\mathrm{N}}, \mathrm{V}^{\mathrm{I}}, \mathrm{k}\right)
\end{aligned}
$$

With the densities given in equation (A11), the log likelihood function can be maximized with respect to the elements in $\Psi$ (equation (A6)). 


\section{The Empirical Results}

All of the empirical results in this paper are based on the log likelihood in equation (A14). The most general results, presented in Table 4 and column (4) of Table 6, are based on estimates of all four parameters in $\Psi$. The results in Table 3 and column 3 of Table 6 are based on the assumption that there is no leakage of information during holidays; hence, $\Psi=\left(\mathrm{V}^{\mathrm{N}}, \mathrm{V}^{\mathrm{I}}, \mathrm{k}, \lambda=0\right)$. In this case, for a given $\mathrm{k}$, the first summation in equation (A14) depends only on $\mathrm{V}^{\mathrm{N}}$. Given this estimate of $\mathrm{V}^{\mathrm{N}}$, the second summation determines $\mathrm{V}^{\mathrm{I}}$. The results in Table 2 and column (2) of Table 6 are based on the assumption that returns are distributed normal. The Scaled-t distribution converges to the normal and provides a good approximation to the normal when $\mathrm{k} \geq 30$; hence, $\Psi=\left(\mathrm{V}^{\mathrm{N}}, \mathrm{V}^{\mathrm{I}}, \mathrm{k}=30, \lambda=0\right)$. In this case, the first summation in equation (A14) depends only on $\mathrm{V}^{\mathrm{N}}$, the second summation depends only on $\left(\mathrm{V}^{\mathrm{N}}+\mathrm{V}^{\mathrm{I}}\right)$, and we obtain the well known equality between maximum likelihood and method of moments estimates of the variances when returns are normal (cf. equations (3) in the text).

\section{Likelihood Ratio Test}

The noise ratio statistic, $\mathrm{NR}=\mathrm{V}^{\mathrm{N}} /\left(\mathrm{V}^{\mathrm{N}}+\mathrm{V}^{\mathrm{I}}\right)$, is a ratio of two random variables. Under certain conditions, this ratio is distributed Cauchy, which has neither a mean nor variance, and therefore can not be evaluated directly for hypothesis testing. However, since the parameters are estimated by maximum likelihood, we can test certain hypothesis about NR by comparing the likelihoods associated with unrestricted and restricted models. Restrictions are imposed by relating $\mathrm{V}^{\mathrm{N}}$ to $\mathrm{V}^{\mathrm{I}}$ such that $\mathrm{NR}$ equals a particular value. For example, suppose we want to test a $\mathrm{NR}$ of 0.5 . In this case, we restrict $\mathrm{V}^{\mathrm{N}}$ to be equal to $\mathrm{V}^{\mathrm{I}}$. In general, if the null hypothesis is NR $=\varphi, \mathrm{V}^{\mathrm{N}}=(\varphi /(1-\varphi)) \mathrm{V}^{\mathrm{I}}=\Phi \mathrm{V}^{\mathrm{I}}$. 
To test the validity of these restrictions, we use a likelihood ratio test. The maximum likelihood estimates of the unrestricted $\left(\Psi^{\mathrm{U}}\right)$ and restricted $\left(\Psi^{\mathrm{R}}\right)$ parameter vector are as follows,

$$
\begin{aligned}
& \Psi^{\mathrm{U}}=\left\{\hat{\mathrm{V}}^{\mathrm{N}}, \hat{\mathrm{V}^{\mathrm{I}}}, \hat{\mathrm{k}}, \hat{\lambda}\right\}, \\
& \Psi^{\mathrm{R}}=\left\{\mathrm{V}^{\mathrm{N}}=\tilde{\Phi \mathrm{V}^{\mathrm{I}}}, \tilde{\mathrm{V}^{\mathrm{I}}}, \tilde{\mathrm{k}}, \tilde{\lambda}\right\},
\end{aligned}
$$

where the ${ }^{\wedge}$ and ${ }^{\sim}$ superscripts indicate estimated values for the unrestricted and restricted models, respectively. If the restriction is valid, the values of the unrestricted and restricted log likelihood functions should not be too far apart as assessed by the likelihood ratio test statistic, $\operatorname{LR}(\Phi)$,

$$
\mathrm{LR}(\Phi)=-2\left\{\ln \mathrm{L}\left(\Psi^{\mathrm{R}}(\Phi)\right)-\ln \mathrm{L}\left(\Psi^{\mathrm{U}}\right)\right\}
$$

where $\operatorname{LR}(\Phi) \sim \chi_{\mathrm{r}}^{2}$ and $\mathrm{r}$ is the number of restrictions (one in this case). The $\mathrm{p}$ values associated with equation (A16) for the null hypothesis that $\mathrm{NR}=\varphi=0.1$ $(\Phi=(1 / 9))$ are presented in column 7 of Table 2, column 6 of Table 3, and column 7 of Table 4. 


\title{
CESifo Working Paper Series
}

\author{
(for full list see www.cesifo-group.de)
}

1748 Olaf Posch and Klaus Waelde, Natural Volatility, Welfare and Taxation, June 2006

1749 Christian Holzner, Volker Meier and Martin Werding, Workfare, Monitoring, and Efficiency Wages, June 2006

1750 Steven Brakman, Harry Garretsen and Charles van Marrewijk, Agglomeration and Aid, June 2006

1751 Robert Fenge and Jakob von Weizsäcker, Mixing Bismarck and Child Pension Systems: An Optimum Taxation Approach, June 2006

1752 Helge Berger and Michael Neugart, Labor Courts, Nomination Bias, and Unemployment in Germany, June 2006

1753 Chris van Klaveren, Bernard van Praag and Henriette Maassen van den Brink, A Collective Household Model of Time Allocation - a Comparison of Native Dutch and Immigrant Households in the Netherlands, June 2006

1754 Marko Koethenbuerger, Ex-Post Redistribution in a Federation: Implications for Corrective Policy, July 2006

1755 Axel Dreher, Jan-Egbert Sturm and Heinrich Ursprung, The Impact of Globalization on the Composition of Government Expenditures: Evidence from Panel Data, July 2006

1756 Richard Schmidtke, Private Provision of a Complementary Public Good, July 2006

1757 J. Atsu Amegashie, Intentions and Social Interactions, July 2006

1758 Alessandro Balestrino, Tax Avoidance, Endogenous Social Norms, and the Comparison Income Effect, July 2006

1759 Øystein Thøgersen, Intergenerational Risk Sharing by Means of Pay-as-you-go Programs - an Investigation of Alternative Mechanisms, July 2006

1760 Pascalis Raimondos-Møller and Alan D. Woodland, Steepest Ascent Tariff Reforms, July 2006

1761 Ronald MacDonald and Cezary Wojcik, Catching-up, Inflation Differentials and Credit Booms in a Heterogeneous Monetary Union: Some Implications for EMU and new EU Member States, July 2006

1762 Robert Dur, Status-Seeking in Criminal Subcultures and the Double Dividend of ZeroTolerance, July 2006 
1763 Christa Hainz, Business Groups in Emerging Markets - Financial Control and Sequential Investment, July 2006

1764 Didier Laussel and Raymond Riezman, Fixed Transport Costs and International Trade, July 2006

1765 Rafael Lalive, How do Extended Benefits Affect Unemployment Duration? A Regression Discontinuity Approach, July 2006

1766 Eric Hillebrand, Gunther Schnabl and Yasemin Ulu, Japanese Foreign Exchange Intervention and the Yen/Dollar Exchange Rate: A Simultaneous Equations Approach Using Realized Volatility, July 2006

1767 Carsten Hefeker, EMU Enlargement, Policy Uncertainty and Economic Reforms, July 2006

1768 Giovanni Facchini and Anna Maria Mayda, Individual Attitudes towards Immigrants: Welfare-State Determinants across Countries, July 2006

1769 Maarten Bosker and Harry Garretsen, Geography Rules Too! Economic Development and the Geography of Institutions, July 2006

1770 M. Hashem Pesaran and Allan Timmermann, Testing Dependence among Serially Correlated Multi-category Variables, July 2006

1771 Juergen von Hagen and Haiping Zhang, Financial Liberalization in a Small Open Economy, August 2006

1772 Alessandro Cigno, Is there a Social Security Tax Wedge?, August 2006

1773 Peter Egger, Simon Loretz, Michael Pfaffermayr and Hannes Winner, Corporate Taxation and Multinational Activity, August 2006

1774 Jeremy S.S. Edwards, Wolfgang Eggert and Alfons J. Weichenrieder, The Measurement of Firm Ownership and its Effect on Managerial Pay, August 2006

1775 Scott Alan Carson and Thomas N. Maloney, Living Standards in Black and White: Evidence from the Heights of Ohio Prison Inmates, 1829 - 1913, August 2006

1776 Richard Schmidtke, Two-Sided Markets with Pecuniary and Participation Externalities, August 2006

1777 Ben J. Heijdra and Jenny E. Ligthart, The Transitional Dynamics of Fiscal Policy in Small Open Economies, August 2006

1778 Jay Pil Choi, How Reasonable is the 'Reasonable’ Royalty Rate? Damage Rules and Probabilistic Intellectual Property Rights, August 2006

1779 Ludger Woessmann, Efficiency and Equity of European Education and Training Policies, August 2006 
1780 Gregory Ponthiere, Growth, Longevity and Public Policy, August 2006

1781 Laszlo Goerke, Corporate and Personal Income Tax Declarations, August 2006

1782 Florian Englmaier, Pablo Guillén, Loreto Llorente, Sander Onderstal and Rupert Sausgruber, The Chopstick Auction: A Study of the Exposure Problem in Multi-Unit Auctions, August 2006

1783 Adam S. Posen and Daniel Popov Gould, Has EMU had any Impact on the Degree of Wage Restraint?, August 2006

1784 Paolo M. Panteghini, A Simple Explanation for the Unfavorable Tax Treatment of Investment Costs, August 2006

1785 Alan J. Auerbach, Why have Corporate Tax Revenues Declined? Another Look, August 2006

1786 Hideshi Itoh and Hodaka Morita, Formal Contracts, Relational Contracts, and the Holdup Problem, August 2006

1787 Rafael Lalive and Alejandra Cattaneo, Social Interactions and Schooling Decisions, August 2006

1788 George Kapetanios, M. Hashem Pesaran and Takashi Yamagata, Panels with Nonstationary Multifactor Error Structures, August 2006

1789 Torben M. Andersen, Increasing Longevity and Social Security Reforms, August 2006

1790 John Whalley, Recent Regional Agreements: Why so many, why so much Variance in Form, why Coming so fast, and where are they Headed?, August 2006

1791 Sebastian G. Kessing and Kai A. Konrad, Time Consistency and Bureaucratic Budget Competition, August 2006

1792 Bertil Holmlund, Qian Liu and Oskar Nordström Skans, Mind the Gap? Estimating the Effects of Postponing Higher Education, August 2006

1793 Peter Birch Sørensen, Can Capital Income Taxes Survive? And Should They?, August 2006

1794 Michael Kosfeld, Akira Okada and Arno Riedl, Institution Formation in Public Goods Games, September 2006

1795 Marcel Gérard, Reforming the Taxation of Multijurisdictional Enterprises in Europe, a Tentative Appraisal, September 2006

1796 Louis Eeckhoudt, Béatrice Rey and Harris Schlesinger, A Good Sign for Multivariate Risk Taking, September 2006 
1797 Dominique M. Gross and Nicolas Schmitt, Why do Low- and High-Skill Workers Migrate? Flow Evidence from France, September 2006

1798 Dan Bernhardt, Stefan Krasa and Mattias Polborn, Political Polarization and the Electoral Effects of Media Bias, September 2006

1799 Pierre Pestieau and Motohiro Sato, Estate Taxation with Both Accidental and Planned Bequests, September 2006

1800 Øystein Foros and Hans Jarle Kind, Do Slotting Allowances Harm Retail Competition?, September 2006

1801 Tobias Lindhe and Jan Södersten, The Equity Trap, the Cost of Capital and the Firm's Growth Path, September 2006

1802 Wolfgang Buchholz, Richard Cornes and Wolfgang Peters, Existence, Uniqueness and Some Comparative Statics for Ratio- and Lindahl Equilibria: New Wine in Old Bottles, September 2006

1803 Jan Schnellenbach, Lars P. Feld and Christoph Schaltegger, The Impact of Referendums on the Centralisation of Public Goods Provision: A Political Economy Approach, September 2006

1804 David-Jan Jansen and Jakob de Haan, Does ECB Communication Help in Predicting its Interest Rate Decisions?, September 2006

1805 Jerome L. Stein, United States Current Account Deficits: A Stochastic Optimal Control Analysis, September 2006

1806 Friedrich Schneider, Shadow Economies and Corruption all over the World: What do we really Know?, September 2006

1807 Joerg Lingens and Klaus Waelde, Pareto-Improving Unemployment Policies, September 2006

1808 Axel Dreher, Jan-Egbert Sturm and James Raymond Vreeland, Does Membership on the UN Security Council Influence IMF Decisions? Evidence from Panel Data, September 2006

1809 Prabir De, Regional Trade in Northeast Asia: Why do Trade Costs Matter?, September 2006

1810 Antonis Adam and Thomas Moutos, A Politico-Economic Analysis of Minimum Wages and Wage Subsidies, September 2006

1811 Guglielmo Maria Caporale and Christoph Hanck, Cointegration Tests of PPP: Do they also Exhibit Erratic Behaviour?, September 2006

1812 Robert S. Chirinko and Hisham Foad, Noise vs. News in Equity Returns, September 2006 